\title{
Unified phylogenetic species concept: taking subspecies and race out of science: postmodern theory applied to the Potamophylax cingulatus group (Trichoptera, Limnephilidae)
}

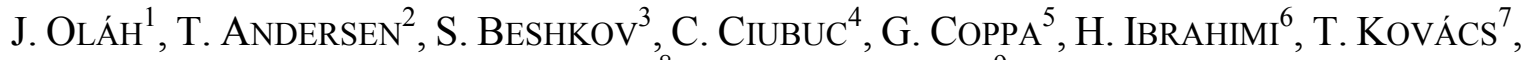 \\ J. OLÁH ${ }^{8}$ JR. \& B. SZCZESNY ${ }^{9}$
}

\author{
${ }^{1}$ János Oláh, Residence postal address: Tarján u. 28, H-4032 Debrecen, Hungary.E-mail: profolah@gmail.com \\ ${ }^{2}$ Trond Andersen, Department of Natural History, University Museum of Bergen, University of Bergen, P.O. Box \\ 7800,N-5020 Bergen, Norway.E-mail: trond.andersen@um.uib.no \\ ${ }^{3}$ Stoyan Beshkov, National Museum of Natural History, 1 Tsar Osvoboditel Blvd. 1000 Sofia, Bulgaria. \\ E-mail: beshkov@nmnhs.com \\ ${ }^{4}$ Constantin Ciubuc, Sinaia Zoological Research Station, University of Bucharest, Cumpatu 5, Sinaia, R-106100, \\ Romania.E-mail: ciubuc1206@gmail.com \\ ${ }^{5}$ Gennaro Coppa, 1, rue du Courlis, F-08350 Villers-sur-Bar, France. E-mail: gennaro.coppa@wanadoo.fr \\ ${ }^{6}$ Halil Ibrahimi, University of Prishtina, Faculty of Mathematics and Natural Sciences, Department of Biology, \\ Mother Teresa p.n., 10000 Prishtina,Kosovo.E-mail: halilibrahimi@yahoo.com \\ ${ }^{7}$ Tibor Kovács, HNHM Mátra Museum, Kossuth Lajos u. 40, H-3200 Gyöngyös, Hungar. kaoti@t-online.hu \\ ${ }^{8}$ János Oláh jr., Residence postal address: Tarján u. 6, H-4032 Debrecen, Hungary. \\ E-mail: sakertour@gmail.com \\ ${ }^{9}$ Bronislaw Szczesny, Institute of Nature Conservation, Polish Academy of Sciences, Kraków, Poland. \\ E-mail: szczesny@iop.krakow.pl
}

\begin{abstract}
The subspecies of the biological species concept with incomplete reproductive isolation versus the incipient sibling species of the phylogenetic species concept with permeable reproductive barrier are still applied side by side in the everyday practice of taxonomy. Both terms refer to the same organisms diverged mostly in allopatry with various stages of reproductive isolation. Question remained: how human ranks these entities organised by nature? The reliable ranking of living hierarchies is retarded and even obscured by the suppressed state of taxonomy. Disappointing scenario: the science of biodiversity is stuck in century old macromorphologies without innovation of fine phenomics and without exploring its hightech and high-throughput potential. The empirical science of taxonomy is "modernised" by the neutral DNA marker industry diverting the epistemological focus from empirical to virtual. Virtuality of noumenon is used to camouflage the phenomenon of the adverse environmental processes, the wasteful byproducts of the profit oriented liberalized economy. The sensual reality of species and the accelerated species extinction is effectively masked by the virtual sciences of the abstract: numbers, data, statistics, algorithms, equations, models and ideas. To understand the birth of a young incipient species we have briefly reviewed the postmodern development of the unified phylogenetic species concept. (1) The reality of species and higher phylogenetic taxa. (2) The biological and phylogenetic species. (3) How to delineate phylogenetic species? (4) The infinite versus finite division of phylogenetic species. (5) The construct of the unified species concept. (6) Taking subspecies and race out of science. Without recognition of incipient siblings of the phylogenetic species the biodiversity remains underestimated and the pharisaic anti-science ranking of humans remains with us. The discovery of speciation trait that is the sexual adaptive structures in reproductive barrier building, which are detectable by fine phenomics, gives perspective to find the finite division, the dynamic initial split in the continuous process of diversification. The speciation traits produced by integrative organisation, as opposed to competitive selection, help to unify the operational criteria of the biological species concept that is the speciation by reproductive isolation with the general concept of phylogenetic species that is the causal process of the separately evolving metapopulation lineages. The subspecies and racial ranking is untenable anymore, we suggest taking subspecies and race out of science: the finite division of the initial split detected by speciation traits is the birth of the phylogenetic incipient sibling species. There is no "subspecies"and "races", as there is no "subindividual" in the biological organisation. In the present caddisfly taxonomy the subspecies remained as a valid status in the Potamophylax
\end{abstract}


cingulatus caddisfly species group. With a clear distinction between the neutral and adaptive traits in the $P$. cingulatus species group and applying the subtle and stable shape divergences in phallic fine structures we have proposed to change the taxonomic status of subspecies to incipient sibling phylogenetic species rank: Potamophylax alpinus stat. nov., $P$. depilis stat nov., $P$. ibericus stat. nov., $P$. inermis stat. nov., reinstated the species status of $P$. cingulatus stat. restit. and we have described three new species: P. fesus Oláh, P. portugalicus Oláh et Szczesny, and $P$. transalpinus Oláh \& Coppa, spp. nov.

Keywords. Suppressed taxonomy, speciation trait, race, subspecies, phylogenetic species, sibling species, Potamophylax cingulatus species group, new species.

\section{INTRODUCTION}

$\mathrm{T}$ axonomy is staggering today in postdarwinian contradictions remained non-harmonised as regards the ever-lasting conflict between epistemology of ranking and ontology of organisational hierarchies: that is (1) how human ranks entities and (2) how entities are organised in nature. What are species, subspecies or races as organised by nature and as ranked by science? In spite of these indispensable questions waiting to be understood, our taxonomy that is the basic empirical and integrative discipline of natural history for answering such questions appears more and more as a neglected and almost dying science. Why taxonomy is suppressed? Is there any cultural interest or social context not to answer these questions, especially the last one: what are races? This happens in the middle of the biodiversity crisis amplified by global warming. Today all the achievements of high-tech and high-throughput potential of the fine phenomics, the empirical future of taxonomy, is repressed and retarded by the over financed blind neutral DNA marker industry. Taxonomists realise their backyard position every day in the western culture: there is no sound genuine taxonomic project possible to launch without at least one component of the modern slogans fabricated in masking industries: DNA sequencing, warming models or evolutionary theories.

\section{Is taxonomy suppressed?}

The painful result of this desperate state is clearly documented by the simple fact that "modern" taxonomy, at least our caddisfly taxonomy, is based and practiced primarily on the century old procedures of macromorphologies. The species descriptions and drawings of the Russian scientist Martynov $(1909,1915)$ are still comparable to, or even exceed the quality of many of our present-day drawings and structural understandings. This stagnant condition in taxonomy was created and maintained by non-taxonomists and by distracting movements. In the last eighty years the "modernization" of taxonomy was focused by highly speculative models of mathematicians (Haldane, Fischer, and Wright) and by virtual molecular approaches manifested in neutral DNA sequences of geneticists (Dobzhansky). Virtual artefacts of speciation processes, taxon ranking and species delineations are further deformed by dictates of ideological and political projects generated in the dominating practices of Darwinism. This kind of "modernization" is getting more transparent today as an intentional movement to replace and to divert the focus from empirical to virtual. Virtuality of noumenon (thing-in-itself, Kant's Ding an sich) is always flexible enough, compared to phenomenon, to camouflage the ongoing adverse environmental processes, the byproducts of the unlimited and unregulated profitoriented human activities. Nature consumption is accelerated by the guiding ideology of the unleashed economic man in the sensible world of the living creatures. The sensual reality of accelerated extinction is effectively masked by the virtual sciences of the abstract: ideas, numbers, data, statistics, algorithms, equations and models.

The present taxonomic scenario is disappointing. Over-discussed questions of nature and natural hierarchies remained unanswered or even obscured in a genuine phylogenetic perspective by reams of virtual DNA clades. Answers are misled and manipulated by ideological contexts: what are species, what are subspecies and what are the problematic races? Despite of Darwin's desperate trials, the ranking and organisational hierarchies remained contradictory. Placing discrete bounda- 
ries on the continuous process of diversification in the universe has produced endless debate, especially in the human created realms of subspecies and races. The product oriented nature-exploitive and competitive western culture has significantly influenced the process-oriented and more naturecooperative eastern cultures and getting worldwide dominance by globalization. Destroying nature resources and ecological services are emerging symptoms of modern western ideology. These simple symptoms are distracted by "green" movements to such euphemistic slogans like "ecological footprint" in order to camouflage the ideological reality of consumption-idiotism behind: why /how we accelerate the rate of nature consumption. During this permanent "progress" most resources have been removed from the taxonomy, from the only integrative science to answer directly and openly these questions. Funds are channelled and disposed either to genetics or to the social projects of evolution. As a result, our taxonomy remained mostly stuck in the century old pathway of macromorphology and intentionally unarmed by the lack of modern revisions, synopses and monographs.

\section{Taxonomic state in the Potamophylax cingulatus species group}

No progress has yet been realised in the taxonomic application of the empirical resources of the fine phenomics. This huge innovative potential of taxonomy has been left without human and financial resources. Its intrinsic and innate empirical nature is almost suppressed by the piles of virtual neutral molecular markers. But science has self-generating innovative power acting even in such a neglected discipline like taxonomy as has been presented by Szczesny (1990) and Moretti et al. (1994).

Here we sample and apply some theoretical achievements of the phylogenetic species concept to a particular creatures of caddisflies with unsettled taxonomy. One of the initial fine phenomic approaches to caddisfly taxonomy was realised in the Potamophylax cingulatus species group by comprehensive comparative studies on the fine structures of the phallic organ. Stable shape divergences have been discovered both in the aedeagus and the paramere structures and independent taxa have been discussed, but the possibility of species polymorphism was considered at least by a question mark (Szczesny 1990). High polymorphism was suggested again, but not documented in a recent study (Martinez et al. 2016), and the historical polymorphism being a sympatric phenomenon has been debated in the Potamophylax genus (Oláh 2017). In a detailed study on the fine structure of the aedeagus and the parameres the polymorphism was not supported and the shape divergences exhibiting high stability as well as coupled with allopatry permitted to delineate and to describe several new subspecies in the Potamophylax cingulatus group (Moretti et al. 1994).

The discovery of the selective/adaptive speciation trait (Oláh et al. 2015, 2017) has initiated concentrated research first (1) on the fine structure and function of the caddisfly intromittent organ as well as (2) on the structural organisation of periphallic organs, especially the paraproct. Among the periphallic organs the paraproct (intermediate appendages) is the structure more intimately involved in the cryptic female choice during the copulation processes. These selective traits proved to be sensitive enough to detect early stages of reproductive isolation serving the function of reproductive barriers delimiting incipient species of the unified phylogenetic species concept.

In this paper (1) we review briefly how the unified phylogenetic species concept has been evolved; (2) how to take subspecies and race out of science; (3) how it is applicable to the taxonomy of the Potamophylax cingulatus species group; and (4) why the previously supposed polymorphism and the still existing taxonomic rank subspecies (or race) in reality represent independent incipient sibling species. However, based on our theoretical considerations (Oláh et al. 2017) our first motivation was to examine and to convert the subspecies status, still unsettled in the stenophylacini tribe, to phylogenetic sibling species status in this caddisfly group. 


\section{THEORETICAL PART}

\section{Species concepts}

Contemporary systematics is getting to reformulate the taxonomic practices by a demanding perspective to delimit and to describe taxa based on phylogenetic history. Yet, non-phylogenetic and non-history based species concepts, like the biological species concept, still remains popular. Species concepts should not conflict with evolutionary history, but often do. Therefore, it is reasonable to argue for the necessity of a phylogenetic species concept (Velasco 2008). Species is a confusing homonym with three meanings: (1) name of a taxonomic rank (a level or rank in Linnaean hierarchy, a taxonomic category); (2) word to a particular taxon of that rank, (ontological category, different kinds or ways of being); (3) word to the concept of an evolving group of organisms. This ambiguity is disparate ontologically, but related semantically (Hey et al. 2003). Confusion arises often between the species as taxa, (groups of organisms with shared set of traits) and the species as evolving group of closely and multiple related individuals.

Species concepts serve two disciplines: taxonomy and evolutionary theory (Cracraft 1987). Accordingly the term species has two basic functions: (1) the species category as a rank in the Linnaean hierarchy created by taxonomist for grouping organisms and (2) the species as taxa with a location in space and time and referring to objective, observable entities, to living objects perceptible by touch (Mayr 1996). Species are dynamic, evolving individuals, almost like a quantum systems but human attempts to force them into rigid classes. Species are real evolutionary groups as well as the human-made categories created by subjectively perceived distinction. The neo-Darwinian synthesis treated the biological species ambiguously as real or subjectively delimited, discrete or nondiscrete, irreducible or decomposable into smaller units depending on particular groups of organisms. How to maintain the unity and discreteness of species in the Darwinian evolutionary transformations along the branches? How entities can be discrete and still transform over time? These difficulties can be alleviated if species are defined in terms of evolutionary process, as a product of evolutionary phenomena incorporating small genetic changes and the mechanism of natural selection (Cracraft 1987) or rather an alternative idea of integrative organisation (Oláh et al. 2017).

Species is not real. The old linear view of species evolution driven by mutations, recombination and selective pressure and producing a distinct product of species is slowly replaced by a more complex reality of species differentiating, diverging, merging and reverting while driven by diverse integrative mechanism against external and internal impacts. As a result, most of the species categorization applied by taxonomists is inherently and obligatory arbitrary (Hunter 2006).

Many believe that species rank does not exist; it is not a real category in nature. Darwin doubted the distinction between species and varieties thinking that species is indefinable in spite of the title of his book "Origin of Species". Despite scepticism over the species category, there are pragmatic reasons for keeping the word species: the species taxa that are the groups of organisms are real (Ereshefsky 2010). Many genetic studies have re-examined taxonomies of various groups of organisms based on morphology and frequently uncovered paraphyletic or polyphyletic groupings, confirming or refuting previous interpretations. Studies on mitochondrial DNA diversity concluded that mtDNA data and traditional morphological taxonomic assignments tend to converge (Avise \& Walker 1999). The same data have been revisited with an opposite conclusion (Hendry et al. 2000): the mtDNA discontinuities do not match recognised taxonomic species. Species realities have been questioned, species category abandoned and new descriptive scheme was suggested for grouping organisms by specifying the amount of differences in various traits at any levels of the phylogenetic tree of life. This conclusion was independent of the marker types used to identify discontinuities. It was interpreted by fundamental flaws in the species paradigm. Today it is clear 
that expectation to find any direct correspondence between neutral markers and adaptive phenomic splits is a naïve unfounded reductionist trial (Oláh et al. 2015).

Only species is real tangible objects. Originally Dobzhansky (1935) has given undisputable ontological significance to the biological category of living individuals. Later (1937), while bringing the Mendelian genetics and the Darwinian evolution together, he has drawn the attention that species are the most stable units in taxonomic practice, as compared either with infraspecific categories such as variety, race, subspecies, or supra-specific ones such as genus, or family. During this Modern Synthesis species was treated as fundamentally different entity from taxa of higher and lower levels in the hierarchy of biological organisation. According to this misleading concept only the species taxon is the product of evolution, functioning in a direct way as gene pools; exist as whole, as real things (Mayr 1942, 1963). The term species refers to a phenomenon of the nature; species are concrete describable objects. Contrary to species, higher or lower taxa were viewed as subjective and arbitrary, not as an existing real entity (deQueiroz 1985). In the New Systematics the species definable as distinct selfperpetuating units with an objective existence have a greater reality in nature, as dynamic evolving entities that exist independently of human observer. Species have a greater degree of objectivity, than higher taxonomic categories which are not definable in this concrete way (Huxley 1940). This view is still survived repeating that ranking above or below species level is more subjective and ranks above species are relational, lacking the biological reality of the species (Claridge 2010).

Besides questioning the reality of higher taxa along the species tree in the name of modern synthesis, the new systematics has produced more severe disaster with long lasting consequences culminating today in the biodiversity epoch. Modern Synthesis has started to undermine the science of taxonomy by giving priority to experiments, statistics, ecology and genetics and downgraded the empirical descriptive and comparative nature of taxonomy. Literally suggesting that "an increase in the scientific staffs of the museums is urgently needed if they are to escape from the burden of routine description and naming" of species (Huxley 1940 p. 38). After the new systematics arrived to replace taxonomy most of the available funds moved to genetics in the name of taxonomy. The second disaster came to taxonomy in the present biodiversity epoch when museums are intentionally converted to "baby-sitter centres" instead of regaining their real function of collecting, describing and naming species before their extinction. The core mission of taxonomy is to collect, discover, describe and classify units of biodiversity, the living companies of the human being.

All phylogenetic taxa are real tangible objects. In his phylogenetic systematics Hennig (1950, 1966) has radically changed this ontological controversy created by the New Systematics of the Modern Synthesis (Dobzhansky 1937, Huxley 1940). He has incorporated the role of evolution in understanding and formulating higher taxa. Similarly to species the higher level taxa are real, tangible product of evolution. They exist above species level as monophyletic groups composed of the constituting ancestral species, a complete system of common ancestry, an adequate clade, and as the natural outcome of the process of evolutionary descent. The only evolutionary significant property of higher taxa is whether they comprise this monophyletic clade or not. Genera and families exist as a whole of complete monophyletic clades, outside of the mind of taxonomists (deQueiroz \& Donoghue 1988). Higher taxa are real and no any level in the hierarchy is biologically more significant than any other. The weakness of treating species and higher taxa together is that species boundaries are delimited by theoretically well supported qualitative methods, and in contrast, boundaries of higher taxa are subjected to quantitative study, and their patterns is not explained adequately due to lack of theories (Barraclough 2010). Yes, in studies on the evolution of biodiversity the species are the fundamental evolutionary units. From the very beginning of life history studies huge primary 
practical and secondary theoretical data has been accumulated in their phenomics by empirical comparative observations of qualitative nature. Qualitative phenomics in taxonomy are self-explanatory, like in fractal languages or in medical treatment strategies, including cancer failures and cognitive reflections work (Oláh et al. 2015, 2017) Contrary, higher taxa are intensively studied mostly quantitatively by algorithms and models as well as by never tested presumptions, thought experiments.

Velasco (2008) gave crucial demonstrative role to phylogenetic tree to understand phylogenetic inferences. Trees help to visualize important concepts such as what a monophyletic group is and how it is constituted by an ancestral and all of its descendants or how two species are reciprocally monophyletic having all haplotypes of one species more closely related to each other than any haplotypes from his sibling and vice versa. Tree thinking makes easy to understand how recency of common ancestry, not morphological (morphological species) or interbreeding (biological species) similarity, that defines genealogical relationships. Besides giving real tangible existence to higher taxa on the tree of life, the phylogenetic systematics has initiated a theoretical transformation or rearrangement of the outdated biological species concept into the phylogenetic species concept.

Biological species concept. Darwin (1859) has replaced the Platonic idea and the Aristotelian typological "form" or "essence" concept of species based on type specimen by the evolutionary species concept of the lineage segment, "branches in the lines of descent". However, the old tradition of species category remained intact functioning further as a rank in the taxonomic hierarchy and predetermined a species concept with fixed temporal and spatial stage, an adult stage at the artificial time-slices of lineages instead of dynamic lineage or branch along the line of descent. Challenged by the spreading ideas of the phylogenetic systematics the discrete boundaries of the "adult" biological species on the continuous process of diversification along branches of lineage segments has produced endless debate and developed multitudes of species concepts (Mayden 1997). The essence of the widely accepted biological species is the discontinuity created and maintained by reproductive isolation representing groups of interbreeding natural populations that are reproductively isolated from other such groups (Mayr 1996). The short definition of the biological species concept is: "Species are groups of interbreeding natural populations that are reproductively isolated from other such groups". However, the species criterion of reproductive isolation is not applicable to the reticulate evolution, to organisms with asexual reproduction as well as to the classification of fossil organisms.

The ontology of the biological species concept is incorrect. It lacks generality, not applicable to asexual organisms and inextensible in time. An evolutionary analysis demands temporal extensibility. The evolutionary phylogenetic species concept has been formulated and started to challenge the spatial and temporal blindness of the biological species concept. The naïve full-fledged biological species concepts of the New Systematics and the Modern Synthesis have retarded taxonomy upon the morphologically well separated architecture of the "adult" biological species with reproductive isolation. The lack of perfect reproductive isolation is the reason why a subspecies, although distinct morphologically, are not a biological species. Biological species concept cannot be applied to the temporal dimension of species; unable to specify precisely the limits of species in time; not sensitive enough to recognise adequately the phylogenetic incipient species. Biological species represent a fixed stage of evolutionary divergence; a stage in the evolutionary stream where interbreeding groups of individuals became segregated and split into two or more groups incapable to interbreed (Dobzhansky 1937). Large geographically subdivided populations or polytypic biological species often comprising multiple evolutionary entities with or without evolutionary cohesive interbreeding. These entities are inherently ambiguous, difficult to demarcate clearly even with intensive field research and applying probabilistic threshold with the classic " $75 \%$ rule". 
Biological species and its focus on reproductive isolation is a product of the Modern Synthesis, but in fact conflicts with much of the current evolutionary thought and distorts history. Reproductively isolated groups might be nonmonophyletic and creating problems in phylogenetic tree building in diferent ways (Velasco 2008). (1) Paraphyly problem: biospecies can be paraphyletic composed of some, but not all, of the descendants of some ancestral population; there are two populations, one than splits, one of the splitted lineages becomes reproductively isolated from all the others. (2) No tree problem: further speciation events within this paraphyletic biospecies makes real tree building nonsensical. (3) Wrong tree problem: further speciation events within this paraphyletic biospecies produces wrong tree. The history of reproductive isolation, ecological divergence or morphological divergence of speciation events does not define evolutionary history.

The widespread and dominating biological species concept (Mayr 1942) is not in accordance with the new findings that reproductive barriers are semipermeable to gene flow and species can differentiate despite on-going interbreeding (Hausdorf 2011). Biological species concept lumps well differentiated species that nevertheless interbreed regularly. In the unified phylogenetic species concept the species category is being decoupled from the hierarchy of taxonomic ranks and transferred to the hierarchy of biological organisation (deQueiroz 2011). In the old concepts the species as a rank was accepted only if its lineage had reached a particular stage in the process of divergence. Externally allopatric or intrinsically (internally) isolated sympatric (functional allopatry) populations may show every degree of divergence up to that of "full" species (Wilson \& Brown 1953). Lineages that had not yet reached that stage were ranked as subspecies, semi-species or named whatever, like form, variety or race. Biological species are not comparable entities. The polytypic species contain a variable number of subspecies, well differentiated evolutionary units or arbitrary subdivisions of continuous spatial variation others include only one monotypic species. For Darwin the distinction along the lineages, lumping or splitting, was unimportant, because polymorphic variants, clinal variations, forms, geographic races, subspecies, con-species, incipient species and "good" species formed a continuum, the "branches in the lines of descent" (Mallet 2007).

The phylogenetic species. Species are irreducible discrete groups of countable individuals with reproductive cohesion (not disjunction) delineated by heritable diagnostic characters through space and time and exposed to patterns and processes of evolution along the branches in the line of descent. The phylogenetic species is the smallest irreducible, but diagnosable monophyletic group of individual organisms; the smallest set of lineages descended from a common ancestor possessing derived, apomorphic traits with unique evolutionary history that is with parental pattern of ancestry and descent (Cracraft 1987). Phylogenetic species concept is typological in the sense that it is relying upon diagnostic characters in delineation. In the phylogenetic species concept the evolutionary relationships dominates over fertility, contrary to the groups of reproductively isolated interbreeding populations of the biological species concept. If species splitting has not yet reached diagnosability or reproductive cohesion the cluster of species is in statu nascendi (Dozhansky \& Spassky 1959). To rely on reproductive cohesion instead of disjunction is rather reasonable since species and individuals of different higher taxa are frequently interbreeding. Grizzly and polar bear breed in nature (Mallet 2008) and intergeneric hybrids are well documented among fishes (Burkhead et al. 1991, Garrett 2005), snakes (LeClere et al. 2012) birds (Graves \& Zus, 1990, Graves 2007), and primates (Jolly et al. 1997). Interbreeding of closely related sibling species seems to be a general phenomenon in speciation processes induced along secondary contact zones. Interbreeding is rather a rule and not a coincidence or exception, under the control of reproductive cohesion and corrected by reinforcement and character displacement.

In our taxonomic modal analysis on caddisflies the entity of phylogenetic species diverged or diverging by fine structures of the reproductive 
barriers, defined by specific initial split criterion, and detected by the degree of morphological difference as an indication of the underlying degree of reproductive isolation. The phylogenetic incipient species is recognised by the diagnostic characters of speciation traits. This is the structure representing reproductive barrier of the biological species concept as well as manifesting potential negative fitness effects in copulating processes. In this way the phylogenetic incipient species concept focuses on the earliest stages of speciation. Adaptive speciation trait to separate and describe species has been successfully applied recently in detecting, delineating and describing over two hundred caddisfly siblings (Oláh et al. 2012, 2015, 2017, Oláh \& Oláh 2017), combining in practice the essence of the phylogenetic and biological species concepts: initial split by reproductive isolation.

How to delineate phylogenetic species? There is inherent subjectivity in all kind of species delineation, like in any kind of entity delineation down to quantum level. In most research fields, but particularly in quantum physics and in human behavioural research the observation has a direct effect on the outcomes (Hey et al. 2003). Understanding reality is limited by the capacities of observer, by his mental processes and influenced by his interest. Every cogniser has a different relative being of anything. Even the "absolute beings" could be observed from infinity of Nietzsche's perspectives and could be described by infinity of potential properties or aspects (Oláh et al. 2017). Similarly debated is the role of taxonomists playing in the creation of species taxa by taxonomic rank designation.

Species delimitation is frequently confused with species conceptualization. This results in controversy concerning definition of species category and the methods to detect species boundaries. The primary species criterion of the separately evolving metapopulation lineage is widely accepted for species conceptualization. According to this general lineage species concept species are segments of population-level lineages. There is however disagreement about the various secon- dary species criteria, the operational species criteria, those no longer considered relevant to species conceptualization but only to species delimitation that is to assess lineage separation: (1) intrinsic reproductive isolation, (2) diagnosability, (3) monophyly (Queiroz 2007a, b). Most contemporary species concepts are consistent with the idea that species are evolving lineages or evolving populations. Taxonomic uncertainty is rooted in the evolutionary nature of species; therefore it is unlikely to be solved completely by standardization (Isaac et al. 2004). Many diverging organisms are still able to mate and produce viable offspring, frequently in contact zones. Changing environment may accelerate divergences on ecological time scales of hundreds or a few thousands of years reinforced by character displacement, reaching a point of no return. Contrary there are convincing cases for reverse speciation where lineages seemed to converge again; with an increasing number of hybrids speciation may go into a reverse, reaching a point of separation reunite (Hunter 2006).

An epistemological problem remains however, how to delineate species in space and time along these continuously changing lineages? It might be very difficult to assess empirically a particular taxon. Taxonomist's tools, circumstances, including sensual and mental capacities and personal interest influence the weight to be given to neutral or adaptive traits and to their particular pattern of variation in designating and describing new species taxa. Taxonomic entities are evolutionary and demographically dynamic, often not very distinct and can change over time or regularly in contact zones (Hey et al. 2003). Moreover, boundaries of all entities are sharp or fuzzy depending upon the spatial and temporal scales of detection that is on the spatiotemporal point of view of the observer (Cracaft 1987). Species, genera and families represent different nested monophyletic clades with temporal scales of separations. They are tangible taxa integrated on population level in the groups of individuals inside of these nested monophyletic clades and along the time course of phylogenetic divergences. 
How to establish fixed stages for any taxa in the dynamic evolutionary stream of processes permanently working over incipient species, mature species, or incipient genera? Taxonomist's question is what criteria help to identify species taxa? Evolutionist's question is what criteria aid best to discover locations, boundaries and properties of evolutionary entities? Finding initial split criteria of the phylogenetic species concept may help to answer both questions. Discovering initial split helps to draw the lines of demarcation among evolving entities. The essence of the phylogenetic species delineation is to recognise the first empirical (and/or genomic) sign of the early stages of reproductive barrier building in reproductive cohesion (not disjunction!). Due to ephemeral stages of the continuous process of differentiation and the lack of widely accepted easy or obvious thresholds indicating when speciation has been completed, that is an oversimplified detection of initial splits is troublesome (Winker 2010).

The problem of possible infinite division. Final argument against the phylogenetic species concept refers to the theoretical and practical possibility of the infinitely fine divisions for initial splits to differentiate among diverging groups of reproductive cohesion. With whole-genome analyses any two individuals become diagnosably different and could be supported by different monophyly. Character/gene trees and organismal trees are controversial and contradictory: taxa can be monophyletic for one character and non-monophyletic for another and cladograms are really "cloudograms" superimposed by lineage reticulation. The testable, therefore objective diagnosability and monophyly can be found at any level of hierarchy, but question remains where to draw the lines between lineages? Diagnosability and the smallest cluster depend on the resolution power of the character analyses. Diagnosability and reciprocal monophyly, that is the monophyly with respect to each other, could be produced by extinction of intermediate forms (Zachos \& Lovari 2013). With enough traits all individuals are diagnosable from each other.

The apparently infinite division is further supported as well as distracted by the reductionist assumption incorporated in all algorithms and models of phylogenetic reconstruction, both by DNA sequences and by unrooted phenetics of numerical taxonomy, that divergence (splitting the lineages) occurs in nature, not reticulation (melding of lineages). But in nature reticulation (the bête noir for cladistics) dominates over divergence and integration over selection according to the general organisational system: aggregates of element in interaction (Botnariuc 1967). Both the reticulation and divergence, like the nature itself, are organised in fractal pattern occurring in the largest and in the smallest, irreducible cladistics units. Fractal is the nature's geometry and organises itself by the negentropy of integration, reticulation against the entropy of disintegration, divergence and selection. Introgression type of reticulation, by melding of lineages, tends to generate phylogenetic discordance more effectively among closely related groups of species, unlike lateral gene transfer. The amount of gene flow by introgression and reticulation of hybridisation is vastly underestimated (Mallet et al. 2015).

Finite division by speciation super traits. The common vernacular argument against phylogenetic species is that every single organism is genetically and phenetically unique. Yes, like every quantum in the Universe! No, because like every quantum, while trying to integrate itself to maintain its integer state, is transformed finally into new emergent entity of natural kind powered by the organising forces of integration (Oláh et al. 2017), and balancing around an idea expressed as nominal kind. Emergence is the appearance of a new observable that cannot be derived from the root theory (Longo et al. 2015). Only reductionism, like phenetic species concept in taxonomy and phenetic clade construction in systematics believes that a system can be reduced to the sum of its part. In organizational systemic hierarchy diversification is based on emergence of new entities and the emergent properties differ from those of the constituent subunits (Botnariuc 1967). Similarly, species as emergent entities are not divisible infinitely into smaller units. Several protective mechanisms evolved in time to produce stable emergencies and to defend their produced 
integrity. Species level organisational emergency cannot be subdivided further if the produced entities of the initial splits are delineated by adaptive traits of the reproductive barrier. In this case the shared derived characters of monophyletic clades are the adaptive structure itself which is creating and maintaining the reproductive isolation. Further subdivision is highly resisted by selection or sexual integration, and the introgression of hybridization may occur without strongly affecting the genomes. But genomic admixture of reticulation nevertheless is realised if the introgressed alleles are established. The adaptive structures of the initial split are stable and highly protected.

The initial split is a symbol for a dynamic temporal dimension representing the genesis of lineage, the splitting of lineage, the birth of a new lineage entity. Initial split is recognised by operational criteria of the various species concepts during the delimitation process of the splitted entities. The splitted is a real entity in nature, a phylogenetic, evolutionary lineage. Species are entities that form lineages or lineage-forming biological entities (deQueiroz 1999). Split entities are gradually becoming more and more differentiated; reproductively incompatible, ecologically distinct, phenetically distinguishable, diagnosable, and reciprocally monophyletic. Depending on the different contemporary species concept and adopting their different priorities for properties of species delineation, disagreement and conflicts are inevitable as well as group specific, how to recognise exact temporal splitting of the separately evolving lineage. Species are clusters of organisms passing a threshold of divergence determined by one or several operational criteria. Thresholds for each operational criterion should be fixed by experts of disciplines under the principle of avoiding oversplitting. However, threshold finding should not be realised by numerical or mathematical evaluation systems and neither by putting together unjustified operational criteria, like adaptive shape divergence and neutral DNA markers under the name of multi-source integrative taxonomy (Seifert 2014).
Initial split of diverging species could be recognised not only by detecting direct signs of reproductive isolation or presenting other phylogenetic branching events, but simply empirically by the rarity of hybrids and intermediates between clusters and species (Mallet et al. 2015). These adaptive structures of initial splits are the speciation super traits frequently detectable only by fine phenomics (Oláh et al. 2017). However, in routine observation the speciation super traits seem stable and subtle products of adaptive speciation processes integrated in allopatric isolation and their stability is organised and maintained by several integrative and protective genomic mechanisms (Oláh \& Oláh 2017). These protective mechanisms may create nonlinearity in the effect of primary gene flow, or in the secondary one across contact zones, on the processes of divergences, especially in the genomic building of reproductive barriers. This is why even at high rates, gene flow cannot prevent speciation driven and established by adaptive traits of reproductive barriers.

In delimiting the smallest diagnosable cluster of individual organisms there is focus on phenotypic evidences setting aside genetic data (Tobias et al. 2010): (1) proper nucleotide data are not yet sufficiently available; (2) what is available has no relation to the adaptive structures of initial splits; (3) no widespread agreement on how nucleotide data can be used to delimit species. Examining larger portion of the genome to pinpoint specific genes associated with the observed phenotypic differences of the initial split (Patten 2010) seems not very promising to answer the basic questions how to detect initial splits in speciation. There are no well-defined genes, in the sense of the traditional Mendelian term, exist behind the traits of the initial splits (Oláh et al. 2017). There is however, thousands of sequences with almost infinite combinations of pleiotropic, epistasis and epigenetic mechanisms behind minor shape divergences. Frequently they are undetectable empirically, diagnosable only with virtual geometric morphometrics. It seems that the adaptive, therefore stable and subtle shape divergen- 
ces, establishing a reproductive barrier, are created and supported by very complex genomic processes. Moreover protein-coding sequence convergence in the early branches of the tree of life and high level of incomplete lineage sorting in contemporary divergences make lineage delineations challenging even with whole-genome analyses (Jarvis et al. 2014).

Underestimated biodiversity. Without recognizing phylogenetic incipient species the biodiversity is much underestimated by relying upon the outdated and overly lumped alpha taxonomy of "adult, "full" or "good" species (Pratt 2010). The traditional subspecies concept identifying minimum diagnosable units in allopatry as terminal taxa could be essentially synonymous with the phylogenetic species concept (Remsen 2010). This is clearly confirmed indirectly by the findings that in a meta-analysis of molecular phylogenetic monophyly (Zink 2004) only 3\% or in a new global meta-analysis (Phillimore \& Owens 2006) around $36 \%$ of avian subspecies represent distinct phylogenetic lineages as measured by the neutral mitochondrial DNA marker. This is not surprising, because neutral markers are unable to measure adaptive traits of subspecies involved in the initial splits while building the reproductive barriers. Much geographic variation may arise via selection; therefore, DNA tests restricted to selectively neutral genetic data are misleading, neutral markers are not associated directly and firmly with local adaptation. Selection yields distinct phenotypes invisible to neutral markers (Patten 2010). In spite of these finding mixed teams of taxonomists and geneticists remained on the old pathway of trying to couple any kinds of phenotypes with routine neutral markers. They are lucky if, by accident, shapes and neutral sequences fit to each other. If not, Procrustes superimposition starts working. Our distinction between nonadaptive neutral and adaptive non-neutral morphological traits demonstrates that neutral markers are rather blind and not sensitive enough to detect the real on-going adaptive selection processes, that is the adaptive molecular mechanisms creating the divergences on relevant loci pro- ducing the speciation traits in the early stages of speciation (Oláh et al. 2015, 2017). The lack of congruence between phenotypic traits and neutral molecular data, particularly at sibling species or at subspecies level (Cicero 2010) is very indicative. It refers to adaptive processes triggering and governing diagnosable traits just at or around the initial splits. The evidence of the detected overall incongruences directly suggests that subspecies could be incipient phylogenetic species, representing the early stages of speciation (Mayr 1942, Phillimore 2010). Moreover, a genuine consensus about subspecies concept is difficult to achieve, because trinominal epithets may cover heterogeneous mix of evolutionary phenomena and cannot be classified as strict science in the fuzzy world of realism (Fitzpatrick 2010).

\section{Taking subspecies and race out of science}

Unified species concept. After fundamental theoretical studies deQueiroz $(2007 \mathrm{a}, \mathrm{b})$ has suggested a unified species concept. He has clearly distinguished and separated the causal processes that produce the lineages (how nature works!) and the operational criteria used to recognize them in practice (how human ranks!). Different species concepts are just tools of the taxonomists in order to find species in their various lifecycles along the stages of speciation. He has retained the general concept of species as separately evolving metapopulation lineages that is the causal process, the only necessary property of species. All the other properties are treated as contingent properties and treated as necessary for considering lineages to be species: phenetically distinguishable, diagnosable, monophyletic, intrinsically reproductively isolated, and ecologically divergent. These properties remain important first (1) as operational criteria to delineate species as evidences of lineage separation for the existence of species and second (2) to define subcategories or recognise different classes of species precisely, based on the given properties: reproductively isolated species, diagnosable species, monophyletic species, ecologically differentiated species. This clear separation of the conceptual problem of defining species category from the methodological problem of 
species delimitation helps research by focusing disagreement to species delimitation with a more demanding perspective for searching species boundaries. The shift in the conceptualization of species category in the unified species concept reducing species criterion to the separately evolving metapopulation lineages has a number of consequences for taxonomy: (1) undifferentiated and undiagnosable lineages are species; (2) all evolutionary lineages, both distinct and indistinct, are species; (3) accepting the integrative framework of unified species concept, biologist must regard lineages that merit recognition of species; (4) morphologically indistinct "cryptic" lineages are diagnosable by other operational criteria (Naomi 2010); (5) species can fuse; (6) species can be nested within other species lineages; (7) species category is the old taxonomic rank; (8) a shift from viewing species category as one member of the hierarchy of taxonomic ranks to viewing it as a natural kind whose members are the units at one of the levels of biological organisation; (9) encouraging taxonomist to develop new methods of species delimitation (deQueiroz $2007 \mathrm{a}, \mathrm{b})$; (10) shift from classifying organisms to testing hypotheses about lineage boundaries and phylogenetic relationships (deQueiroz 2005). However, the reality of this shift, from describing species to phylogenetic studies, is unjustified; altogether over 100 million (Lee 2016) or including prokaryotes one to six billion (Larsen et al. 2017) species is waiting to be discovered, recognised and described before their extinction. This unified species concept was working behind and influenced our studies to discover the speciation super traits as a new method of species delimitation for initial splits, as well as helped us to recognise and to describe over two hundred incipient caddisfly species during a few years, mostly in the sky islands of the so called well studied European mountain ranges (Oláh et al. 2015, 2017, Oláh \& Oláh 2017). Moreover, if we go into the details and study its roots and its postmodern background philosophy, the unified species concept applies a refined fuzzy version of the old essentialism, going back to Plato and Aristotle.

Fuzzy essentialism. We have been devising and using taxa from the very beginning, ever since our ancestors evolved the capacity for language, on an essentialist basis of species. This was enforced later by Platonic and Aristotelian essences and killed recently by Darwin, who has fostered, rather than settled questions about what species really are. There is untapped information in our mind and in our language: species are categories of natural kinds (Hey 2001). However, evolutionary biologists are more interested in the entities of evolutionary groups and not in the mental contributions to taxa. The natural kinds with perceived degree of distinction are based on their essences represented and manifested by varying individual entities. The evolutionary groups might or might not be distinct in space and time, capable of myriad ways of gene exchange to create groups within groups over time. The species problem is fostered by the conflicting motivations to recognise categories of natural kinds with real essences and to understand evolutionary groups. Anti-essentialist critiques are often misplaced and unproductive (Haslam 1998). We have to remember that entities in the set theory are (1) crisp, deterministic, and precise in characters; (2) dichotomous of yes-or-no, rather than more-or-less; (3) and dual of true-or-false, rather than in between. But complexity of entities increases along organisation of natural kinds. Our ability to make precise statements becomes almost mutually exclusive, both ontologically and epistemologically. Probability and uncertainty theories have been developed to model these uncertainties of reality. Fuzzy set theory is one of these theories, generated to exceed dual logic of classical set theory in order to understand continuity and discontinuity in the ever-changing structural reality starting from quantum sets to sets of living entities.

The world is a collection of objects, assorted into types (Kitcher 2007). In the ontology of biological entities the taxa are natural kinds with real essences of balancing equilibrium underlined by variability ranges of character states including hidden microstructure that scientifically discoverable, essential to the kind, and making the kind what it is. Ideas, concepts and categories are nominal kinds. The natural kinds are contrasted 
with nominal kinds following Locke's distinction between the real essences of characters that partitions the nature into kinds of entities as metaphysical or ontological reality and the nominal essence of abstract ideas, definitions or categories mediated by human concepts. Natural kind is ontic structural realism (1) how entities are organised in nature. Nominal kind is epistemic construal (2) how human ranks entities. The ever changing clinal essentialism of natural kinds, as contrasted with Plato and Kant, is composed of distinct components (Haslam 1998): (1) core of necessary properties; (2) inherent or intrinsic hidden structures underlying superficial properties in supervenience; (3) determinate extensions even with vague boundaries defined by these properties; (4) underlying intrinsic properties are causally related to the accessible characters; (5) despite developmental transformations and graded variation the essential sameness is stable; (6) great inductive potential with wide variety of inferences and generalisations.

Historical concept of race. The concept of race divides Homo sapiens into a small number of groups based on some type of (1) biological foundation, (2) discrete racial grouping, (3) inheritance, (4) genealogy of geographic origin, and (5) physical phenotypes. Conceptual, ontological, epistemological and normative controversies have been accumulated due to ambiguities and confusions generated during race boundary delineation; due to moral status of racial identity and solidarity; due to justice and legitimacy of policies; due to institutions and aimed at undermining racial inequality (James 2017). Three competing schools of thought form three metaphysical camps. (1) Racial naturalism holds the old biological conception of race bearing biobehavioral essences with underlying natural heritable genetic and phenetic properties explaining behavioural, characterological, and cultural predispositions of individual entities of racial groups. (2) Racial constructivism holds that even if biological race is false, races exist through human culture and human decisions. (3) Racial scepticism of eliminativists holds that races of any type do not exist and racial naturalism is false and recommends discarding the concept of race entirely.
Metaphysics of race or subspecies. Biological research on race motivated by or lending credence to underlying racist attitude created great pains for scientists to deny the existence of biological human race. Nevertheless, human races adapted to particular environments do in fact exist (Pigliucci \& Kaplan 2003). Already Voltaire wrote, wellpacked with Locke's empiricism, that only blind people could doubt that there are different races (subspecies). People, like any other living creatures, can be classified according to their differences detected, experienced, measured and described in taxonomical studies by various traits of gross morphology, fine phenomics or genetic structure. There are emergent entities exist, like phylogenetic species in spite of speculative trials to formulate arguments against the reality of biological races from blind (neutral) genetics, relativity, and anti-racism. Natural kind is a group of objects characterised by some trait-variability equilibrating around objective essence that is the mind-independent similarity. Social kind is a group of objects with similarity based in existing social practices, institutions, or conventions. Social construction is a classification whose members constitute a social kind. In different sense, but biological realists and social constructivists agree about the reality of race. However, they disagree about the kind of racial categories: biological realists say race is natural kind; social constructivists say race is social kind. Eliminativists say: there are no races; racial attributions are false; race is neither biologically real nor socially real. Social constructivists and eliminativists agree that races are not natural kinds, but they disagree about the reality of races. Social constructivists admit that race is real even though it is not grounded in genetic differences. Eliminativists are error theorist claiming that race is an empty term; nothing belongs to this category; conditions of race criteria are not satisfied by anything (Diaz-Leon 2012).

Taxonomist or evolutionist, the competent authors and users of the species, subspecies, and race concepts maintain that natural property is a necessary condition of taxa. There is no scientific ground for social constructionist view. But this 
view could still be defended by semantic externalism, simply spoken, by support from outside. In conceptual analysis the semantic externalist insights from the critique of the analytic/synthetic distinction can be extended to justify social constructionist position (Haslanger 2006). Moreover, if conditions of natural property satisfied, the naturalism of the biological realists was the correct view. If these conditions not met the view of error theorists were correct.

Philosophical debate on the semantics of general terms and on criteria for real kinds is widening. An obscure concept of basic racial realism to escape the defeat of antirealist position was elaborated by formal logic applying and combining plethora of notions, all packed into the ontological suitcase: social kind, real kind, real social kind, scientifically relevant kind, unkind, kindred, robust kind, basic kind, genuine kind, basic realism, unkind realism, scientific realism (Glasgow \& Woodward 2015). The concept of basic racial realism was intended (1) to provide an exciting and powerful resource for thinking about race; (2) to capture useful and applicable parts of race that we need to make social progress; (3) do not deny that the features that make races are biological features; (4) to decide races still by visible, biological features, not by social properties; (5) but it does not commit to there being real biological races, that fit poorly with ordinary race-talk; (6) avoiding moral disasters that have plagued racial characterization throughout modern history. Basic racial realism suggests in one metaphysical way, that human beings look just different and sorting us into different categories, but those categories are neither biological kinds nor socially dependent kinds. As a result race is neither biologically real nor socially real, it is real all the same, but most important that the new concept camouflages the anti-science byproduct of this tragicomic debate over reality of race, whether race is biologically real, socially real, or simply not real.

Social construction of human race. Social construction of race is realised by impersonal and personal agents highly exposed to contingent choices. Impersonal causal agents (cultures, conventions, institutions) construct by previous visual-conceptual experiences, by powerful prior notions, by background theories, by nonrepresentational phenomena. Personal social agents construct through their choices determined or influenced by scientists' judgement like theory selection, experiment evaluation, as well as by personal interest/power relations. Shift in human classification has been documented to follow the shift of interest and power (Mallon 2014). What is constructed by these agents, the human traits or human kinds, are designed by culture rather than by biology or nature. These agents construct human traits by evaluating inferences from very complex and contradicting social influences in theory production and from the social construction of facts with ungrounded scientific rationality, scientific realism or scientific process (Laudan 1981, Nelson 1994). In contrast, naturalist attitudes towards science are based (1) on epistemological fundamentalism of empiricism and causal modelling; (2) on metaphysical fundamentalism of supervenience and reduction governed by natural laws; (3) on human naturalism of nonanomalism and methodological naturalism (Mallon 2014).

Races are incipient species! Negating natural kind of human races ignores the basic achievements of modern biology (Mayr 2002). In spite of the social and political connotations there is a naturalistic approach gathering strength to stop the social destruction of race (Sesardic 2010). Yes, but there is a sound potential for a scientific destruction of the race! The unified species concept gives a real perspective to take race out of phylogenetics, human genetics and taxonomy. Race is the incipient phylogenetic species, which is the basic concept of Darwinism. There is however, a cost to overcome the century-old debate about the role of race in science. But this cost is not as high as compared to the recently suggested liberal solution to take race simply out of science by slimy substitution dictates in the name of democracy and use of terms like "ancestry" or "population" to describe human groupings. They say that language matters also in racial thinking (Yudell et al. 2016). Instead of this anti-science 
dictate we suggest to apply the unified species concept to solve the century old debate on the race and social racism. The taxon of real race of natural kind with real equilibrating essence must be upgraded to incipient species of siblings under the condition if the emergence is diagnosable by any traits or if reproductive isolation is detectable. Darwinian population thinking represents permanently diverging phylogenetic species with emergence of initial splits of a new evolutionary group. In practice, the initial split is any kind of emerged traits recognisable and delineable by taxonomist. There is no need for a vague race (or subspecies) concept without clear emergence history in the continuum of the ever-changing Schopenhauer's world of will (energy) and representation (individual entities). There is however, real epistemic perspective for the Schopenhauer's contemplative idea (essence, type), the product of art and science that is the idea of a new emerging entity: the species in statu nascendi (Dozhansky \& Spassky 1959). Species has a life cycle like every sets of quantum in the universe. If we apply the unified phylogenetic species concept, instead of race, the debate will be focused on fine phenomics and genetics to detect the initial split when-and-where divergences by adaptive and/or reproductive barrier delineates the newly born species.

Are human races incipient species? Original concept of race is based on some degree of phenotypic similarity: skin, colour, hair texture, facial features, and bone structure. Racial recognition is not based on a single trait, but rather on a number of characteristics (Sesardic 2010). Racial classifications strongly differ in the number of races and their composition. Genetic similarity and genealogy of human populations are inferred from variability of phenotype and molecular markers. Human genetic variation is geographically structured due to partial isolation of human populations during their early history. Therefore it is inaccurate to claim that race is biologically meaningless. Clustering also indicates that individuals have geographic origin or ancestry (Andreasen 1998). On the other hand, partial isolation is seldom demarcated by precise genetic boundaries. Moreover, the genetic variation is often con- tinuous with substantial overlap and this fact invalidates the concept of discrete race (Jorde \& Wooding 2004).

Lewontin's fallacy. An early estimation suggests that inter-racial variation comprises only about $7 \%$ of the total genetic variation (Lewontin 1972). The misinterpretation of this result originated the idea of race as a social construct, arguing that the genetic differences across races are small unable to sort people into races. This position quickly became a tenet of political correctness. Almost the same was documented thirty years later (Rosenberg et al. 2002): within-population differences among human individuals account for $93 \%$ to $95 \%$ of the total genetic variation and differences among human races that are the intercontinental or interracial variability constitute only $3 \%$ to $5 \%$. But even with this low interracial variability they succeeded to identify five main genetic clusters corresponding to the major geographic regions. The same was repeated recently, summarizing that only minimal fraction of alleles and combinations of alleles is restricted to a single geographical region as well as the diversity between members of the same population is very large (Barbujani et al. 2013). These presentations suggest that race is biologically unreal and based on reductionism, like phenetic species concept in taxonomy and phenetic clade construction in systematics. An emerging system like a diverging living organism cannot be reduced to the sum of its part. This phenetic treatment of total variation is based on all the available characters without a priori weightings. This simplistic thinking is stuck in the failures of the numerical taxonomy as well as limited by the low epistemic capacity of the neutral DNA markers (Oláh et al. 2015). The oversimplified sequence or gene-centric theory of speciation is not sensitive enough to quantify mechanisms of epistasis, epigenetics, and regulatory gene expression, the most important processes modifying the continuous traits with small effect sizes (Oláh et al. 2017). Working with neutral sequences we remain in the dark. We study only unweighted traits like numerical taxonomy being very far from diverging spots and evolving islands of 
speciation and producing contradictions between "gene trees and species trees" as well as between phenotypic traits and neutral sequences. The application of this phenetic philosophy created the "Lewontin's fallacy" by swamping inter-racial differences with within race differences completely ignoring the aggregation effect of these inter-group differences in allele frequencies on different loci. Most of the information that distinguishes taxa is deeply hidden in the correlation structure of the data and not simply in the variation of the individual factors (Edwards 2003). Phenetic treatment looks at only one genetic trait at a time, but more information can be derived from looking at the correlation between loci rather than just the loci themselves. This aggregation effect could support a racial taxonomy without a need for big average variation between the races on a locus-by-locus basis (Sesardic 2010).

How much are the human races (subspecies) geographically circumscribed and genetically differentiated? Traits show independent pattern of geographical variation especially in some combinations, but below the minimal thresholds of differentiation. At the same time enough genetic markers may discriminate most local human populations. According to certain genetic surveys and DNA haplotype trees the human races are not distinct lineages. This is not due to recent admixture; human races were never pure (Templeton 1999). $F_{\mathrm{ST}}$ thresholds analysis has found no sharp boundaries separating human populations (Templeton 2013). But $F_{\mathrm{ST}}$ estimates show that interracial variability of humans is comparable to other polytypic species with not essentially lower values (Tetushkin 2001). The relative homogeneity of human gene pool indicates short differentiation time and significant migration between populations. The small but significant differences do not remove doubts in the reality of human races, although genetic distances are generally more distinct among subspecies and races. The doubts are rather well grounded but not enough for a definite rejection of human races (Tetushkin 2001). The reality of human races is still unresolved.
Obscurity and vagueness in human race delineations are not unique. It is rather a rule than exception in studies on species formation along the permanent continuum of biological integration. Many boundaries between taxa of living creatures are usually conventional and arbitrary, similarly to taxonomic rankings. Placing discrete boundaries on the continuous process of diversification produced endless debate and developed over 22 species concepts (Oláh et al. 2012).

Adaptive traits. Clusters of multivariate genetic similarity, even with weighted characters, frequently do not correspond to folk racial categories of phenotypic features. It is not surprising. Comparison of phenotypic traits with neutral molecular markers produces artefact! Most phenotype is very complex and expressed by multigenic genomic processes including pleiotropy and epistasis, through complex regulatory mechanisms and epigenic interactions. There are phenotypes expressed by thousands of genes and millions of variants with unknown aggregations and correlations of adaptive and neutral combinations. The information contents of phenome dwarves those of genome (Deans et al. 2015). The distribution of adaptation trait, like human skin colour follows the geographical distribution of the environmental factor of UV intensity and may develop in genetically differentiated populations. Local adaptations develop in species with differentiation only at the gene loci under selection with little or no genetic differentiation in other regions of the genome. Based upon these findings a conclusion was drawn that human races are indefinable by adaptive traits and different adaptive traits may define discordant groups (Templeton 2013). However an adaptive single trait may define the incipient phylogenetic species by creating reproductive isolation, like the speciation super traits (Oláh et al. 2015). Neutral and adaptive divergences need detailed comparative survey in human taxonomy with geometric morphometrics of fine phenomics and with detecting gene regions of adaptive phenotypic traits and quantifying their frequency distributions. 
Cline distribution. Even at high level of geographic differentiation, the skin colour variation is clinal, varies continuously along clines, not well described by discrete racial categories (Relethford 2009). But the classic pattern of clinal variation is not entirely supportive against species delimitation; rather it is a direct indication of the interaction at least along both the primary and secodary contact zones between two or more taxa. Primary intergradation zones develop gradually in the process of constant contact between all participating populations. Secondary intergradation zones develop from contact of once separated and significantly diverged populations. Continuous and gradual variation along clines detected in human populations refers to the complex effect of both types, with the dominance of the primary intergradations (Tetushkin 2001). It seems that the presence of transient intermediate populations along a cline is not against the existence of two independent races. Similarly, the almost completely smooth gradient is not against the existence of youth and old age (Dobzhansky 1963).

Racism and/or adaptation superiority. The father of the "Modern Synthesis", that is the conflation of systematics with genetics, or the fusion of forms and genes, Dobzhansky has developed the genetic race concept from (1) arrays of forms or clusters, (2) through genetically distinct geographical population, (3) to genetically distinct Mendelian populations (Gannett 2013). Despite of this early scientific grounding, there is still an illicit separation of Homo sapiens from the rest of the world in the western culture of Bible, contrary to the unified existence of nature in the eastern cultures of Veda and Tao. Racism became a very sensitive ideological and political issue due to selective misunderstanding of the biological organisation launched by the Darwinism and primitively simplified to the struggle for life in the western culture against cooperation and integration. Misled by this unbalanced attitudes of interest and power there is still no consensus on the concept of the race. Based on their old cultural heritages the significant majority is in favour of it in China, and against the concept in the USA (Štrkalj 2006). Especially in the recent past the four-letter world of race became highly avoidable, as if Homo sapiens were not being a living creature. Mayr (2002), the other father of "Modern Synthesis", emphasizes that race is the product of the modern biology, and recognising races is only recognising a biological fact. But in the same paper he declared that there is no biological basis for racism. But again in the same paper he exemplified that, due to adaptation, an Eskimo is superior on the Greenland ice where a Bushman is inferior, and vice versa! Whether the high IQ or the warmheartedness is superior or inferior, it depends on the social environment and on the cultural traditions. According to genetic mechanisms, all human, like any other living creatures are composed of admixtures of intrinsic genetic superiority and inferiority produced by adaptation and superimposed by epigenetics, phenotypic and developmental plasticity, cultural transmission as well as by the complex fabric of eco-evo-devo mechanism (Oláh et al. 2017). In this context Homo sapiens does not differ from any other entities of the living world!

Anti-science position. Western social norms effectively prohibit the assumption that there are biological (phylogenetic) distinctions among human races and disapprove any conflating or ranking research on race or subspecies along the divergence continuum of speciation. Due to the spirit of market pragmatism the legitimacy of race depends upon its suitability to our purposes (Kicher 2007). How applicable is the race concept in medical and criminal industries or in the nature-nurture debate. The unreasonably simplistic dictate by racial scepticism or racial constructionism in the "nature versus nurture" debate seems losing ground and turning slowly to the scientific status of "nature-cum-nurture" scenario (Sesardic 2010). The struggle to define the interaction of nature and nurture is getting productive and promising, and questions are emerging (Tabery 2014, Sesardic 2015): (1) how the complex medical traits like clinical depression, behavioural traits like criminality, or cognitive traits like intelligence are organised by complex mechanisms in both the genome and in the phenome; (2) why and how the overly gene- 
centric theory failed to progress in genetics; (3) how single gene concept is replaced by multigenic cooperation; (4) how complex traits are constructed in development, co-constructed with their environment and not simply programmed by single genes or multigenic complexes; (5) how epigenetics, epistasis, regulatory gene expression are able to integrate complex psychological traits.

In spite of the scientific achievements the antiscience position is still supported and persistently maintained by philosophers, sociologists and politicians as well as by many armchair taxonomists. They unreasonably believe in that dominant tenet, that teaching the nonexistence of race, gives real, long-lasting supports for race talk eliminativism (Mallon, 2006). This position can be easily utilised to take on political overtones through posturing and provocative statements in the political arena. These peoples are far from the empirical sciences they have never analysed personally any species populations (Mayr 1996), and as already Darwin (1844-1846) said no one has the right to examine the question of species or race who has not "minutely examined and described many". Due mostly to social sciences this disgusting term intentionally lacks clear definition and more that systematics and genetics reveals about race, the more biological meaningless the term seems (Ledford 2008).

Harmony between human ranking and speciation. For today the conceptualization of species as dynamic cluster of population lineages under permanent impacts of variously adverse, neutral or beneficial perturbations, as well as integrating or diverging in external or internal types of isolation, is common to all species concepts. Dropping the various species ranking criteria as well as stopping to treat the species as a taxonomic rank, the species taxon, likewise subspecies, semispecies and race, is no longer considered as a fixed stage in the lineage divergence. All these separately evolving metapopulation lineages or segments of lineages represent species, either being new born or just budding nascent entities. The term lineage refers to an ancestor-descendant series of metapopulation, an inclusive population of connected subpopulations (demes) extended through time. It is not a clade or monophyletic group made up of several lineages of branches (deQueiroz 2007a, b).

Biological and phylogenetic species could be equivalent if the former is monotypic. If the biological species is polytypic comprising of two or more separately evolving lineages of discrete taxa it may represent an incipient genus. Is Homo sapiens a "polytypic species" (Cracraft 1987) represents an incipient genus? This is the question remained for human genetics and human taxonomy to answer bearing in mind the basic tenet of the unified species concept: species are species during their entire life span, from initial separation (initial split) to extinction. Commonly spoken, species represented by all individuals in its populations, has life cycle, like any other animated or unanimated groups of entities in the Universe, including quantums and quantum sets of human beings! In the course of evolutionary or organisation processes there are newly born and there are dying species. There are no subspecies like an emergent group of entities for a trinominal nomenclatorial system, as there is no "sub-individual" in the hierarchy of the biological organisation. Similarly, there is no race as a group of individuals of any living organisms including humans. With incipient sibling species of the unified species concept we have got the harmony to dissolve the contradictions between human ranking and natural organisation of hierarchies among the emerging organic entities.

Paraphrasing. Finally, summarising our strict epistemic review presented above, we formulate ten paraphrases for our own human sake that is: (1) the newly born son of a politician neo-Darwin is not a sub-Darwin; (2) there are no "subhumans" either among philosophers, sociologists and politicians; (3) there are innumerable, variously mixed and mixing continuum of human lineages; (4) they are not sub-humans; (5) we are all humans diverging/integrating and not selecting along our genome/proteome/phenome networks; (6) we are organising ourselves to our biomes by integrative cooperation/competition, not diverging 
ourselves from others by selection; (7) every living organisms are integrating the permanent flux of adverse, neutral or beneficial internal and external interactions in the ever-changing quantum world; (8) every human individuals, demes, metapopulation and lineages have their own diverse admixtures of superiorities adjusted to their habitat (homelands) according to the principle of adaptive superiority; (9) to harmonize cooperation there is a real need to understand and to delineate the history of human lineages; (10) for the sake of every human lineages there is a harmonising perspective to replace the unbalanced western paradigm of Darwinian selection by the eastern paradigm of cooperation and integration.

\section{MATERIAL AND METHODS}

In order to qualify the stability and variability ranges of the fine structures in searching the initial splits of divergences, that is the first recognised signs of the reproductive barriers there is a need for population sampling. In the common practice of taxonomy we have frequently only a few, or sometimes only single specimen at our disposal for species delineation. But at least for the critical and indicative species of a particular species complex we have to collect long series of specimens to examine which structures are variable freely exposed to neutral stochastic molecular processes or stable under the protection of adaptive molecular processes.

We have collected and/or borrowed altogether 595 specimens for the examination of the speciation traits in the Potamophylax cingulatus species group: alpinus: 30 , cingulatus 113, depilis: 182 fesus: 1, gambaricus: 0, goulandriorum: 18, ibericus: 1, inermis: 8 , latipennis: 214 , portugalicus: 1 seprus: 1, spinulifer: 9, transalpinus: 17 specimens.

Focusing on the stability examinations of the fine structures by high resolution compound microscope every specimens, both males for phallic organ and females for vaginal sclerite complex, have been carefully prepared: (1) abdomen cut between segments VI and VII; (2) clearing in 10\% NaHO just below 100 degree Celsius by permanent visual control; (3) clearing with superfine forceps, carefully removing all the undigested tissues; (4) pulling out phallic organ with forceps in the functional backward direction; (5) window cutting on tergite VIII to examine the dorsal profile of the vaginal sclerite complex.

There are excellent drawings on the speciation trait of the phallic organ prepared and published for each know species with adequate resolution and details (Szczesny 1990, Moretti et al. 1994). Moreover, we have experienced surprisingly high structural stability in the speciation traits of phallic organ at the critical widely distributed species of $P$. cingulatus, $P$. depilis, $P$. latipennis. Therefore, here we have examined the phallic organ of all specimens for structural stability, but we have prepared drawings of the speciation traits only for the three new species.

In this paper we use the term "spines" for the setal structures of the parameres. However, in most cases they are really modified setae with well discernible alveoli.

Depositories. Constantin Ciubuc Private Collection, Sinaia, Romania (CCPC). Coppa Private Collection, France (CPC). Hungarian Natural History Museum, Budapest, Hungary (HNHM). National Museum of Natural History, Sofia, Bulgaria (NMNHS). National Museum, Prague, Czech Republic (NMPC). Oláh Private Collection, Debrecen, Hungary, under national protection by the Hungarian Natural History Museum, Budapest (OPC). Polish Academy of Sciences. Natural History Museum of the Institute of Systematics and Evolution of Animals, Krakow, Poland (NHM-ISEA). The Manchester Museum, University of Manchester, England (MMUE).

\section{TAXONOMY}

\section{Family Limnephilidae Kolenati, 1848 \\ Subfamily Limnephilinae Kolenati, 1848 \\ Tribe Stenophylacini Schmid, 1955 \\ Genus Potamophylax Wallengren, 1891}

\section{Potamophylax cingulatus species group}

The Potamophylax cingulatus species group is most simply defined and diagnosed in the Potamophylax genus by the bilobed cercus. The bi- 
lobed cerci are composed of the less sclerotized, densely setose outer lobe and the heavily sclerotized less setose inner lobe.

Originally two species; Potamophylax cingulatus (Stephens, 1837) and P. latipennis (Curtis, 1834) were known as closely related species having this type of bilobed cerci. Their long obscured taxonomical status was settled when Neboiss (1963) revised the Curtis Collection by examining the type specimens. The next two species with bilobed cerci, $P$. gambaricus Malicky, 1971 was described from Calabria and P. goulandriorum Malicky, 1974 from Greece. In his historical short paper Szczesny (1990) has given due attention first to the significance of fine phenomics in species delineation of caddisflies. He has concluded that $P$. cingulatus is far from being homogenous and has at least three different populations inhabiting different geographical regions isolated from each other. Based on these findings he has organised a team and they established the $P$. cingulatus species group and described five new taxa (Moretti et al. 1994): $P$. alpinus, $P$. inermis, $P$. spinulifer, $P$. depilis, $P$. ibericus. The tenth species of the species group, P. seprus has been described from Albania (Oláh 2011). In this paper we describe three new incipient sibling species based partly on neutral traits, but mostly on the pattern divergences produced by adaptive speciation traits of the phallic organ.

\section{Neutral traits}

Cerci. The identity or synapomorphy of the Potamophylax cingulatus species group is based on the clearly bilobed shape of the cercus. The outer lobe is less sclerotized; this is the usual plesiomorphic character state of the cercus and heavily setose due to its ancestral sensory function. The inner lobe is heavily sclerotized and serrated, fringed with sharp teeth due to stimulatory or/and coupling copulatory function. Most species has long outer lobes, only $P$. latipennis has short outer lobes. Potamophylax fesus has almost monolobed cerci the heavily sclerotized and dentally fringed inner lobe moved mesad.
Paraproct. Both the dorsal arms and the ventral arms are heavily sclerotized. The length and shape of dorsal arms have diagnostic value, the ventral arms form a closed regular triangular frame giving supporting function during operational movement of the tapering dorsal arm. The two dorsal arms located vertically parallel, upward directed, only $P$. goulandriorum and $P$. seprus has laterad directed dorsal arms.

Gonopods. The rod-shaped apical half of the gonopods as well as the very tip of the gonopods seems to have species specific fine structure. However, the very complicated three-dimensional shape and its sculpture very sensitive to viewing plane make it difficult to draw and to examine its variability ranges. In caudal view some species like $P$. latipennis has very slender and $P$. cingulatus very stout apical half of the gonopods.

\section{Adaptive traits}

Dorsal protuberance on the aedeagus. Best visible in lateral view as variously shaped and differently exposed membranous structure of the aedeagus; present about midway on the dorsum of the aedeagus where about the membranous distal third of the aedeagal dorsum starts. It is probably the membranous remnants or parts of the endophallus along the ductus ejaculatoricus. Its presence or absence seems to serves as a stable diagnostic character to delineate taxa in spite of its flexible membranous texture liable to functional impacts of the phallic organ. Present: alpinus, depilis, Absent: cingulatus, fesus, gambaricus, goulandriorum, ibericus, inermis, latipennis, seprus, spinulifer, transalpinus.

Endophallic membrane around the phallotremal sclerotized opening. Variously exposed membranous wrinkled terminal structure is visible at the distal end of the ductus ejaculatoricus and discernible in various shapes between the apical lamellae.

Triangular apical lamellae of the aedeagus. The membranous distal dorsum of the aedeagus is bounded or variously closed by sclerotized lateral 
ridges protracted apicad into a pair of triangular, vertical lamellae. These lamellae form the bifid apex housing the phallotremal cavity with the vertically wrinkled endophallic membrane around the phallotremal sclerotized opening of the ejaculatory duct. The dorsal profile of the bifid apex is rather variable being most exposed to the copulatory functions: most frequently the lamellae are close together, but could be opened wide variously. The fine shape of the lateral profile seems to be a more stable diagnostic character. The lateral profile of the very apical margin on the apical lamellae is rounded, angled, concave or obliquely straight truncate.

Apical tuft of fine spinules on the tip of the apical lamellae. The very tip of the triangular apical lamellae is frequently armed with a tuft of fine spinules. The tuft is composed of various diagnostic numbers of tiny spinules, countable only with compound microscope. The presence or absence of the tuft has diagnostic value. Present: alpinus, depilis, fesus, latipennis, seprus, spinulifer, transalpinus. Absent: cingulatus, gambaricus, goulandriorum, ibericus, inermis, portugalicus.

Modification in rod-shape of the paramere shaft. The paramere shaft forms an elongated rod, only a single species, $P$. seprus has vertically flattened very high plate-like paramere shaft as well as $P$. gambaricus and $P$. spinulifer have slightly basad enlarging paramere shaft.

Straight or sigmoid dorsal shape of the paramere shaft? Dorsal shape of the paramere shaft offers a more stable character value compared to its lateral profile. Straight dorsal shape: cingulatus, depilis, gambaricus, goulandriorum, ibericus, inermis, portugalicus, spinulifer. Slightly sigmoid dorsal shape: alpinus, fesus, latipennis, transalpinus.

Apical spine pattern of the paramere. The number and shape of the apical spines of the paramere have diagnostic value. Single dominating apical spine is present and visible frequently as a continuation of the paramere shaft and supplied only seldom with additional smaller spine: inermis, gambaricus, fesus sp. nov., latipennis, spinulifer, transalpinus sp. nov. The single apical spine is extremely curving upward and anterad accompanied and masked by a tuft of subapical spine: goulandriorum, seprus. Apical dominating spine is accompanied by $1-3$ additional smaller spines adhering to it: alpinus, cingulatus, depilis. ibericus, portugalicus sp. nov.

Spine pattern along the paramere shaft. Discernible mostly with higher resolution. The number of spines and their position is species specific. 3-4 spines present on the dorsum of the basal half of the paramere shaft: alpinus; 2 spines present in middle position on the dorsum: portugalicus sp. nov., 9-10 short spines present on the dorsum along the entire paramere shaft: ibericus; 7-8 short spines present as comb-like row in middle position on the dorsum with additional 2 short spines ventrad and subapicad: fesus. 3-4 spines present on the ventrum in the basal half of the paramere shaft: transalpinus sp. nov.; 5-6 spines present on the ventrum of the middle section of the paramere shaft: latipennis. Paramere shaft without any spines: cingulatus, depilis, inermis.

Subapical spine tuft. Special, very characteristic spine pattern is developed in the form of spine tuft or group of spines in subapical position; with specific spine number, length and curvature: gambaricus, goulandriorum, seprus, spinulifer.

\section{Speciation trait stability}

In the Potamophylax cingulatus species group the shape and pattern stability of the structural traits both on the aedeagus and on the paramere has been recognised early (Szczesny 1990; Moretti et al. 1994). In our study on the 595 specimens the dorsal protuberance, triangular apical lamellae, the apical tuft of fine spinules on the tip of the apical lamellae of the aedeagus as well as the dorsal shape, rod shape modification of paramere shaft, the apical spine pattern, the spine pattern along the paramere shaft, and the 
subapical spine tuft that is all traits of the phallic organ exhibited remarkable stability in the examined species from the very large distributional area: (1) P. cingulatus from Spain through Andora, France, Czechia, England, to Norway; (2) P. depilis from Poland, through Slovakia, Hungary, Romania, Bulgaria, Albania, Kossovo, Montanegro, to Bosnia \& Herzegovina; (3) P. latipennis from Andora through France, Austria, Czech, England, Norway, Slovakia, Ukraine, Romania, Bulgaria, Serbia, Bosnia \& Herzegovia, Macedonia, to Albania.

In the contact zone between $P$. alpinus and $P$. transalpinus sp. nov. we have found hybrids with varying spine numbers. Similar hybrid population has been recorded in the contact zone of $P$. alpinus and $P$. depilis in Czech Republic with reduced number of basal spines on the parameres (Komzák \& Chvojka 2012).

\section{Incipient sibling species}

Here we summarize the taxonomic history, the present taxonomic state and our proposal to modify the taxonomic state for the species. We list the character states of the speciation traits based on the published drawings and on our present examinations for each species and describe together with drawings the three new species. We do not examine the internal relations and the character ranking values in this species group.

\section{Potamophylax alpinus Tobias, 1994 stat. nov.}

Potamophylax cingulatus alpinus Tobias, 1994 in Moretti et al. 1994: "Charakteristisch für das Taxon ist eine dorso-mediane, nicht skletotisierte höckerartige Protuberanz auf dem Aedoeagus (Abb. 3336); ähnlich wie bei C. gambaricus spinulifer (Abb. 31,32 ) sind distale Apicalstacheln vorhanden (Abb. 33). In der basalen Hälfte der Parameren inserieren 2-4 kurze Borsten (Abb. 33, 34), wobei die Zahl auf der rechten und der linken Paramere meist unterschiedlich ist. Der distale Abschnitt der Parameren läuft in einen leicht gebogenen Hauptdorn aus, neben dem noch 1-2 additionelle, oft eng anliegende Borsten vorhanden sind. Verbreitung. Im gesamten Alpenraum (Abb. 27) und nördlich davon Bayerischen Wald."

Potamophylax alpinus Tobias, 1994. Present study: based on the theoretical consideration of the unified phylogenetic species concept as well as on the stability of recorded divergences of the speciation traits in reproductive barriers building we have changed its taxonomic status to an incipient sibling species. stat. nov.

Material examined. Czech Republic, E Bohemia; Železné hory Mts, Cerhovka brook nr. Podmoklany, 8.IX.1998, Malaise trap, leg. F. Bárta (1male, OPC; 1male, NMPC). Czech Republic, S. Moravia, Podyjí/Thayatal NP, Hardeggská vyhlídka, 2.IX.1997, at light leg. J. Macek, (2 males, 1 female, OPC; 5 males, 1 female, NMPC). Czech Republic, C. Bohemia; Brdy Mts, Hostomice pod Brdy, 27.X.1996, at light leg. H. Studničková, (1 male, OPC; 1 male, NMPC). Czech Republic, S. Bohemia, Šumava Mts, Teplá Vltava river below Kvilda, 26.VII.1991, leg. P.Chvojka (1 male, OPC; 2 males, NMPC). France, Savoie Department, Bramans, Ru Ambin en aval de la confluence $\mathrm{Ru}$ Etache, 16.VIII.2009, leg. G. Coppa (1 male, OPC). France, Savoie Department, Beaufort, Le Doron, 1150 m, 10.VIII.2010, leg. G. Coppa (1 male, OPC). Italy, LombardiaGrone (BG), Sentiero del Pianetto, $450 \mathrm{~m}$, N45 43 '22 E9 ${ }^{\circ} 55^{\prime} 00$, 26.X.2005, leg. G. Patera (3 males, 4 females; OPC). Italy, Bergamo Province, Mezzoldo, hydropetric habitat, $1500 \mathrm{~m}$, 4.VIII. 2010, singled leg. O. Lodovici \& J. Oláh (1 female, OPC). Slovenia, Julian Alps, Radovna stream, 21.VI.1988, light leg. J. Oláh (2 males, OPC). Slovenia, Kneza, Knes, Ravne, 28.VII. 1992, leg. L. Ábrahám (1 male, OPC). Slovenia, Styria, Luce Municipality, Kamnik Alps, Podvolovljek, Lucka Bela stream, N45 $19.000^{\prime}$ E14 42’016', 585 m, 9.VII.2013, leg. D. Murányi \& I. Sivec (1 female, OPC).

Diagnosis. As already Szczesny (1990) has recognised the fine structure of the phallic organ is characterized by "phallus terminating at the edges of the apex with bunches of spines and with membranous protuberance on its dorsal side; parameres with hairs." 
Re-diagnosis. Dorsal protuberance on the aedeagus is present. Apical tuft of fine spinules on the tip of the apical lamellae is present. Paramere shaft is an elongated rod, not vertically flattened plate-like and not enlarging basad. Dorsal shape of paramere shaft is sigmoid. The main apical spine is almost straight in lateral view and accompanied by $1-2$ adhering smaller additional spines. On the dorsum of the basal half of the shaft there are 2-4 small spines present.

\section{Potamophylax cingulatus (Stephens, 1837) stat. restit.}

Halesus cingulatus Stephens 1837: 209, "Tawnyochre: antennae brown; eyes black; thorax with its sides dusky; anterior wings pale ochre, immaculate; nervures yellowish-ochreous, faintly edged with a darker tint, the base of some brownish; posterior wings very transparent, pale whitish-yellow, with pale ochreous nervures; abdomen pale tawny, with margins of the segments and its apex blackish; legs tawny, with black spines. Taken in July, in Devonshire."

Stenophylax latipennis McLachlan, 1875 nec Curtis 1834: 130, "Superior appendages are also formed of two lobes, but the outer lobe is very much longer than the inner and narrower, projecting beyond the margin of the segment, the inner lobe strongly crenate and black on its edge." "According to the old notes on Curtis' collection, I consider that this is his latipennis (though it also occurred among his types of stellatus), the examples being large and very pale. The type of cingulatus (Stephens) is one of the abnormally pale individuals usual in this group, with its anal parts protruded in an unnatural manner, but, from this cause, showing their true forms very distinctly. England, France, Belgium, Switzerland, Austria, Italy, Silesia \&c. Probably not occurring in the northern parts of Europe."

Potamophylax cingulatus cingulatus (Stephens, 1837). Moretti et al. 1994: 92, selected as the nominal taxon of the Potamophylax cingulatus species group.

Potamophylax cingulatus (Stephens, 1837). Present study: based on the theoretical consideration of the unified phylogenetic specie concept as well as on the stability of recorded divergences of the speciation traits in reproductive barriers building we have reinstated its taxonomic status to species rank. stat. restit.
Material examined. Andora, Llorts, $1429 \mathrm{~m}$, 10.X.1988, leg. J. Dantart (1 male, OPC). Czech Republic, N Bohemia; Jizerské hory Mts; Jizera River, Rašeliniště Jizery peatbog; 19.VIII.2005 at light, leg. F. Krampl (1 males, 2 females, OPC; 1 male, 7 females; NMPC). Czech Republic, W Bohemia, Krušné hory Mts. Hluboký potok brook nr. Dolní Nivy, 50 $14^{\prime} 24^{\prime \prime} \mathrm{N} 12^{\circ} 36^{\prime} 24^{\prime \prime} \mathrm{E}$, 31.VIII. 2015 , at light leg. J. Šumpich (3 males, 2 females, OPC; 10 males, 3 females, NMPC). Czech Republic, W Bohemia, Chebsko, Libocký potok stream NW Kynšperk (425 m), VI.-X.2006, Malaise trap, leg. P. Chvojka, (3 males, 3 females, OPC; 8 males, 10 females, NMPC). France, Pyrénées-Orientales Department, Valcebollere, Ru de la Jequera, 24.VIII.2011, leg. G. Coppa (1 male, OPC). France, Hautes-Pyrénées Department, Tramezaigues, Marais Rive Droite du Rioumajou Amont de Fredanc, 1540 m, 18.IX.2012, leg. G. Coppa (1 male, OPC). France, HautesPyrénées Department, Arrens Marsous, Source Labardans, Department 1089 m, 24.VIII.2007, leg. G. Coppa (1 male, OPC). France, PyrénéesOrientales Department, Mantet, Alemany, 1800 m, 18.VII.2004, leg. G. Coppa (1 male, OPC). France, Pyrénées-Orientales Department, Eyne, 1200 m, 9.VIII.2011, leg. G. Coppa (2 females, OPC). France, Pyrénées-Atlantiques Department, Arette, Ru de Chousse, 900 m, 30.X.2009, leg. G. Coppa (1 female, OPC). France, PyrénéesOrientales Department, Angoustrine Villeneuve des Escaldes, $\mathrm{Ru}$ de Lac Sobirans Estang Sobirans, 2340 m, 19.VIII.2011, leg. G. Coppa (2 males, OPC). France, Tarn Department, Lacaune, Le Verdoubre Amont de Roumane, 26.VII.2013, leg. G. Coppa (2 females, OPC). France, Puy-deDôme Department, Chambon sur Lac, Ru de la tourbière Zone à Salix lapponum, $1520 \mathrm{~m}$, 13.IX. 2012, leg. G. Coppa (1 male, OPC). France, Puyde-Dôme Department, Chastreix, Ru de la Jarrige, 1233 m, 27.VI.2010, leg. G. Coppa (1 male, OPC). France, Doubs Department, Cléron, Ru de Valbois TM4, 31.VIII.2009, leg. G. Coppa (1 male, OPC). France, Haute-Marne Department, Orquevaux, Amont Captage, 27.IX.2009, leg. G. Coppa (1 male, 3 females; OPC). France, Ardennes Department, Autrecourt, Fontaine de Brouhan, 208 m, 22.VIII. 013, leg. G. Coppa (1 male, OPC). France, Ardennes Department, Saint- 
Menges, Source Ruisseau des dix Frères, 400 m, 23.IX.2013, leg. G. Coppa (1 male, OPC). France, Ardennes Department, Fleigneux, Etang site Brame du Douaire, 384 m, 29.VIII.2013, leg. G. Coppa (2 males, 5 females; OPC). France, Ardennes Department, Illy, la Hatrelle aval, $271 \mathrm{~m}$, 22.IX.013, leg. G. Coppa (4 males, 3 females; OPC). France, Ardennes Department, Fleigneux, Etang Site Brame du Douaire, 384 m, 29.VIII. 2013, leg. G. Coppa (1 male, 4 females; OPC). France, Morbihan Department, Beignon, I'Aff, le Pont de la Lande, 90 m, 21.IX.2009, leg. G. Coppa (1 male, OPC). France, Gard Department, Saint-Sauveur-Camprieu, Source et $\mathrm{Ru}$ du Trevezel près de Aigoual, $1280 \mathrm{~m}, 18$. VII.2007, leg. G. Coppa (1 male, OPC). England, Lancashire, Nelson, Admergill stream, Blacks, 18.IX.1975, leg. A. Brindle (1 male, MMUE). England, Lancashire, Colne, Slipper Hill Reservoir, 27.VIII. 1980 at light leg. A. Brindle (3 males, 1 female; MMUE). Norway, Hedmark, Stol-Elvdal Evenstad, Settefiskannlegget, $61.4242139^{\circ} \mathrm{N}$ $11.1011215^{\circ} \mathrm{E}, 20$. VIII.2016, leg. L. Hagenlund (Rikmyrprosjejektet) (2 males, 1 female; OPC). Spain, Arros, Af Arriu Verrados, 1050 m, 29. X. 2014, leg G. Coppa (1 male, OPC).

Diagnosis. As already Szczesny (1990) has recognised the fine structure of the phallic organ is characterized by "rounded, spineless lateral edges of the apex of the phallus and the parameres without hairs."

Re-diagnosis. Dorsal protuberance on the aedeagus is absent. Apical tuft of fine spinules on the tip of the apical lamellae is absent. Paramere shaft is an elongated rod, not vertically flattened plate-like and not enlarging basad. Dorsal shape of paramere shaft is straight, not sigmoid. The main apical spine curving upward and mesad in lateral view and accompanied by 1-2 adhering smaller additional spines. There are no spines present along the paramere shaft.

\section{Potamophylax depilis Szczesny, 1994, stat nov.}

Potamophylax cingulatus depilis Szczesny, 1994 in Moretti et al. 1994: 99, "Holotypus: Oे (Coll. Szczesny), Polen, Nord-Karpaten, Gorce-Gebirge,
Poniczanka-Fluß, 700 m, 5.VIII.1976. Diagnose: In der Mitte des Aedoeagus stets eine dorsale Protuberanz von unterschiedlicher Form vorhanden (Abb. 40, 45-49, Tab.3), die häufig mit sehr dünnen, spitzen Börstchen besetzt ist (Abb. 50). Parameren enden distal wie bei c. alpinus in einem langen, eiwärts gebogenen Hauptdorn, mit parallel anliegenden additionellen Borstenhaaren (Abb. 42, Tab. 4). Besonderes Maerkmal: keine kurzen Borsten in der basalen Hälfte der Parameren. Verbreitung: Karpaten."

Potamophylax depilis Szczesny, 1994. Present study: based on the theoretical consideration of the unified phylogenetic specie concept as well as on the stability of recorded divergences of the speciation traits in reproductive barriers building we have changed its taxonomic status to an incipient sibling species. stat. nov.

Material examined. Albania, Dibër district, Lurë area, Fushë Lurë, brook in the village, N4148.719' E20¹2.823', 1075 m, 08.X.2012, leg. P. Juhász, T. Kovács, D. Murányi, G. Puskás (1 male, 2 females; OPC). Albania: Bulqizë district, Çermenikë Mts, Ballenjë, open stream, N41 ${ }^{\circ} 21.621^{\prime}, \mathrm{E} 20^{\circ} 14.472$ ', 1365 m, 20.VI.2012, UV light, leg. Z. Fehér, T. Kovács, D. Murányi (2 males, 1 female; OPC). Albania, North Albanian Alps, Ceram, 1200-1300 m, 29.-30.VII.2016, leg. Z. Varga (1 male, OPC). Bosnia \& Herzegovina, Republika Srpska, Gornji Ribnic, Ribnic Spring, N442 24'07.9” E16 48'05.0”, 1.X.2015, leg. P. Juhász \& T. Kovács (3 males, 1 female; OPC). Bulgaria,Vitosha Mts., Kladnitsa, Sv. Nikola, Tanchovitsa, N42 $34^{\prime} 02.9^{\prime \prime}, \mathrm{E} 23^{\circ} 11^{\prime} 41.4^{\prime \prime}, 1100$ m, 3.X.2011, light, leg. Á. Ecsedi, T. Kovács, \& G. Puskás, $(14 \hat{\jmath}, 4$,, OPC). Bulgaria, Rila Mts. Ribni Ez. 31.VII.1987, leg. B. Herzig (1 male, 1 female; OPC). Bulgaria, Rhodopi, Yadenitza above Golyamo Belovo, $1167 \mathrm{~m}, \mathrm{~N} 42^{\circ} 06^{\prime} 15^{\prime}$ " E23 ${ }^{\circ} 54$ '11”, 6.IX.2012, at lamps, light traps leg. S. Beshkov \& M. Beshkova, (14 males, 5 females, OPC). Bulgaria, Vrachanska Planina, above Zgarigrad, the mine galleries, Vratsa District, $845 \mathrm{~m}$, N43.15919 ${ }^{\circ}$ E23.48676 ${ }^{\circ}$, 9.IX.2012, at lamps, light traps leg. S. Beshkov \& M. Beshkova, (14 males, 3 females, OPC). Bulgaria, Rhodopi, on the road to Milevi Skali from Semchinovo, $941 \mathrm{~m}$, N42 09'13" E24 04'12", 5.IX.2012, at lamps, light traps leg. S. Beshkov \& M. Beshkova, (12 
males, 10 females, OPC). Bulgaria, Belasitza Mts. Below Kongur top, $1779 \mathrm{~m}, \mathrm{~N} 41^{\circ} 19^{\prime} 21^{\prime \prime}$ E $23^{\circ} 10^{\prime}$ 51", 27.VIII.2014, leg. S. Beshkov (2 males, OPC). Bulgaria, Pirin Mts. Banska, 41.766 23.424, 1800 m, 31. VII. 2007, leg. L. Ujvárosi \& M. Bálint (3 males, 4 females; OPC). Bulgaria, Blagoevgrad province, Pirin Mts, Bansko, Demyanitsa Stream and its gorge S of the city, $1535 \mathrm{~m}$, N41 ${ }^{\circ} 47.125^{\prime}$ E232 27.688'24.X.2013, leg. J. Kontschán, D. Murányi, T. Szederjesi, (1 female, OPC). Bulgaria, Sredna Gora Mts, near Panagyurski Kolonii, $1119 \mathrm{~m}, \mathrm{~N} 42^{\circ} 35^{\prime} 28^{\prime \prime}$; E0241' 34", 13.VIII.2017, meadow in Fagus forest, lamps, light traps, leg. S. Beshkov \& R. Bekchiev (1 male, OPC). Croatia, Gacka, IX.1982, leg. G. Kardacz (1 male, OPC). Hungary, Zemplén Mts., Lászlótanya, 1.X.1982, light leg. J. Oláh (7 males, OPC). Hungary, Zemplén Mts., Kemence valley, Kemence stream, 4.IX.1984, light leg. J. Oláh (3 males, OPC). Hungary, Jósvafö, 21.VII.1981, light leg. J. Oláh (3 males, OPC). Hungary, Zemplén Mts. Regéc, Rostalló, 4-5.X.1996, leg. Z. Varga \& T. Kovacs (4 males, 2 females; OPC). Hungary, Mátra Mts. Mátrakeresztes, light trap, 11.IX.1986 (2 males, OPC). Hungary, Mátra Mts. Mátrakeresztes, light trap, 25.VIII.1986 (6 males, OPC). Hungary, Mátra Mts. Mátraháza, light trap, 20.IX.1991 (1 male, 1 female; OPC). Hungary, Mátra Mts. Mátraháza, light trap, 11.IX.1991 (2 males, OPC). Hungary, Mátra Mts. Mátraháza, light trap, 1-30.IX.1989 (6 males, OPC). Hungary, Mátra Mts. Mátrafüred, Vízmü, 11.IX.1991 leg. S. Nógrádi (1 male, OPC). Kosovo, Dërmjak village, Hani i Elezit Municipality, $615 \mathrm{~m}$, $42.17264^{\circ} \mathrm{N}, 21.31582^{\circ} \mathrm{E}, 15$. X. 2017, leg. A. Bilalli, M. Musliu and H. Ibrahimi (1 male, OPC). Montenegro, Durmitor Mts. stream, 25.VII.1965. leg. Z. Varga (3 males, 1 female; OPC). Montenegro, Durmitor Mts. Zabljak distr. Uskocki Canyon, Pirlitor, Vrela, N43 $09^{\prime} 42^{\prime \prime}$ E19 ${ }^{\circ} 13^{\prime} 53^{\prime \prime}$, 6.VIII.2014, light leg. S. Beshkov (2 males, OPC). Poland, Gorce Mts. (Type Locality!), Kamienica stream, 26.VI.1985, light leg. J. Oláh (1 male, 1 female; OPC). Poland, High Tatra, Chocholowska valley, Wywierzysko karstic spring, 21.VIII.2009, singled leg. J. Oláh (1 male, OPC). Romania, Jud Hargitha, Sâncrăieni, Valea Mare, 25-26. VII. 1993. light trap, leg. L. Új- városi (1 male, OPC). Romania, Retezat Mts., Bucura stream, below Bucura lake, $2070 \mathrm{~m}, \mathrm{~N}$ : $45^{\circ} 21^{\prime} 27,872 ”$ E: 22॰52' 28,695”, 8.VIII.2015, light leg. J. Kecskés, \& Zs. Pap (1 male, OPC). Romania, Lacu Rosu, Valea Cupas, 950 m, 9.VII. 1981, leg. L. Peregovits \& G. Ronkay (2 males, OPC). Romania, Maramureş county, Muntii Ignis, Deseşti-Stațiunea Izvoare, forest spring at set-

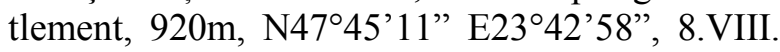
2012 light trap, leg. J. Oláh \& L. Szél ( 2 males, 2 females; OPC). Romania, Maramures Mts. Valea Dragoşa, afl.stg.al râului Moldovița, Cantonul Silvic, "La Craci" Maramureş, 47 40'07" 2539'17", 6-8.IX.2004, leg C. Ciubuc (5 males, 1 female; CCPC). Romania, Maramures Mts. Moisei, Izvorul lui Dragoş, Maramureş, 47 38'45" 24³4'57", 11-14.IX.1995, leg C. Ciubuc (5 males, 13 females; CCPC). Romania, Apuseni Mts. Someşul Cald, la Obârşie (amonte Ic Ponor) 46³7'40" 2246'59", 22-23.VII.2008, leg C. Ciubuc (10 males, CCPC). Romania, Apuseni Mts. Someşul Cald, la Obârşie (amonte Ic Ponor) 46³7'41.72" 2246'57.85" 22-23.VII.2008, leg C. Ciubuc (18 males, 6 females; CCPC). Romania, Bucegi Mts. Coteanu Padina, Bucegi, alt. $1485 \mathrm{~m}, 45^{\circ} 22^{\prime} 35.33^{\prime \prime} 25^{\circ} 26^{\prime} 07.96^{\prime \prime}$, 3.VIII. 2007, leg C. Ciubuc (11 males, 1 female; CCPC). Romania, Făgăraş Mts. Valea Bâlii, 45³6'47.06" 24³6'52.78", 3-4.VIII.2012, leg C. Ciubuc ( 2 males, 1 female; CCPC). Romania, Cibin Mts. Râul Mare afl.dreapta Cibin, Crăciuneasa, $45^{\circ}$ 40'22" 2351'53", 28-29.VII.2009, leg C. Ciubuc (7 males, 1 female, CCPC). Romania, Cindrel Mts. Curpătu Mare, afluent dr.al Sebeşului, Mții.

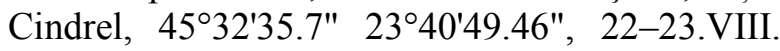
2011, leg C. Ciubuc (11 males, CCPC). Serbia, Vlasina River, $884 \mathrm{~m}, 42.84145^{\circ} \mathrm{N}, 22.82922^{\circ} \mathrm{E}$, 8.XI.2016, leg. H. Ibrahimi and A. Bilalli (1 male, OPC). Serbia, Kopaonik, $1185 \mathrm{~m}, 43.30611^{\circ} \mathrm{N}$, $20.86057^{\circ} \mathrm{E}, 21$. VIII. 2016, leg. H. Ibrahimi and A. Bilalli (1 male, OPC). Slovakia, Banskobystrický region, Javorie Mts, Stará Huta, Blýskavica, Tisovník Stream, N48²7.553' E19 ${ }^{\circ}$ 18.048', 671m, 7-9.X.2013, singled leg. J. Oláh \& L. Szél (3 females, OPC). Slovakia, Banskobystrický region, Javorie Mts, Stará Huta, Blýskavica, Stara Rieka Stream, N48 25.248' E19¹7.822', 764m, 7-9.X.2013, singled leg. J. 
Oláh \& L. Szél, (2 females, OPC). Slovakia, Banskobystrický region, Pol'ana Mts, Hriňová, Bystré, spring brook of Bystrý Stream, N48 $37.569^{\prime}$ E19²9.261', 1025m 8.X.2013, singled leg. J. Oláh \& L. Szél (1 female, OPC). Slovakia, West Tatra, Bela Reka, 22. VII. 1966, light leg. J. Oláh (1 male, OPC). Slovakia, West Tatra, Bela Reka, 3. VII. 1976, light leg. Nagy (3 males, 2 females; OPC). Slovakia, Pavčina Lehota, $500 \mathrm{~m}, 7-8$. VIII.1989, leg. L. Ábrahám (3 males, 2 females; OPC). W Slovakia; Strážovské vrchy Mts; Strážovský potok stream, Predhorie $(430 \mathrm{~m})$; 19.IX.2009; at light, leg. P.Chvojka \& J.Lukáš, (4 males, NMPC; 3 males, OPC).

Diagnosis. As already Szczesny (1990) has recognised the fine structure of the phallic organ is characterized by "phallus terminating at the edges of the apex with bunches of spines and with membranous protuberance on its dorsal side; parameres without hairs."

Re-diagnosis. Dorsal protuberance on the aedeagus is present. Apical tuft of fine spinules on the tip of the apical lamellae is present. Paramere shaft is an elongated rod, not vertically flattened plate-like and not enlarging basad. Dorsal shape of paramere shaft is straight, not sigmoid. The main apical spine curving upward and mesad in lateral view and accompanied by $1-2$ adhering smaller additional spines. There are no spines present along the paramere shaft.

\section{Potamophylax fesus Olah, sp. nov.}

(Figures 1-4)

Material examined. Holotype:Macedonia, Pelister Mts. Planinarski Dom "Shiroka", 1955 m, N41 ${ }^{\circ} 00$ ' 17” E21 ${ }^{\circ} 10$ ' 07”, 6. VIII. 2016, leg. S. Beshkov \& A. Nahirnic (1 male, OPC).

Diagnosis. The cerci are fused monolobed, but the setose outer and sclerotized inner parts still well distinguishable. The dorsal branch of the paraproct is slender in lateral view. Dorsal protuberance on the aedeagus is absent. Apical lamellae of the aedeagus are gradually and re- gularly pointing apicad. Apical tuft of fine spinules on the tip of the apical lamellae is present. Paramere shaft is an elongated rod, not vertically flattened plate-like and not enlarging basad. Dorsal shape of paramere shaft is sigmoid, not straight. The lateral shape is slightly sigmoid. The apical spine is straight without any accompanied additional smaller spines. 2 small spines are present middle on the ventrum of the paramere shaft as well as a dorsal row of 7 short spines in submiddle position.

The new species is most close to and diverged from $P$. latipennis, but differs by having the cerci without bilobed apical margin, the lateral shape of the apical lamellae of the aedeagus differently shaped in lateral view as well, the spine pattern on the paramere shaft different.

Etymology. fesus, comb-like in Hungarian with reference to the dorsal row of short spines or setae on parameres arranged comb like or rather serrated with short spines like a comb.

\section{Potamophylax gambaricus Malicky, 1971}

Potamophylax cingulatus gambaricus Malicky, 1971, 260-261, "Holotypus ô: Calabria, Aspromonte, dint. Gambarie 1300 m, 28. 9. 1970, leg. HARTIG; in meiner Sammlung. Allotypoid $O$ : gleicher Ort, 1: 9: 1970, leg. HARTIG, in meiner Sammlung. Paratypoide: $11 \hat{0}, 6$ 우 in meiner Sammlung, 14 $\overbrace{}^{\lambda}$, 11 우 in coll. HARTIG, alle vom gleichen Ort, leg HARTIG, mit Fangdaten aus verschiedenen Jahren zwischen 8. Juli und 22. Oktober." "In den Kopulationsorganen keine Unteschiede zu Tieren aus den Alpen, durch die außerordentlich helle Färbung aber sehr auffallend."

Potamophylax gambaricus Malicky, 1971. Moretti et al. 1994: 95-96: taxonomic status was raised to species rank.

Material examined. In spite of several trials to borrow there was no any specimen available for a detailed comparative study.

\section{Potamophylax goulandriorum Malicky, 1974}

Potamophylax goulandriorum Malicky, 1974: 116119, "Holotypus $\widehat{\jmath}:$ Olymp-Südseite, östlich Karia, 



Figures 1-4. Potamophylax fesus Olah, sp. nov. Holotype: 1 = dorsal branch of the paraproct in left lateral view, $2=$ cercus in perpendicular dorsal view, $3=$ apical section of left gonopod in perpendicular ventral view, $4=$ paramere and aedeagus of phallic organ in left lateral view.

$800 \mathrm{~m}, 27.10 .1972$; Allotypus + (Puppe): Olymp, Kloster Ajios Dhionisios, 900 m, 13.9.1972; einige Paratypen beider Geschlechter mit den gleichen Daten von diesen beiden Orten sowie vom PindusGebirge: Pertouli (Prov. Trikala), 1300 m, 26.10. 1972; alle Malicky (Privatsammlung)." "Kopulationsarmaturen sehr ähnlich P. cingulatus."

Material examined. Albania, Skrapar district, Ostrovicë Mts, Backë, brook and spring NE of the village, N40³1.346' E20²5.096', $1650 \mathrm{~m}, 12$. X.2012, leg. P. Juhász, T. Kovács, D. Murányi, G. Puskás (2 males, OPC). Tiranë district, Gropë Mts, Vakumonë, karst spring and brook along the road to Elbasan, N41 ${ }^{\circ} 15.109^{\prime}$ E20 $05.805^{\circ}, 1195$ m, 11.X.2012, leg. P. Juhász, T. Kovács, D. Murányi, G. Puskás (2 males, OPC). Bulqizë district, Çermenikë Mts, open brook beneath Mt. Kaptinë, N41 ${ }^{\circ} 23.212^{\prime}$ E20 ${ }^{\circ} 17.506$ ', 1610 m, 10. X.2012, leg. P. Juhász, T. Kovács, D. Murányi, G. Puskás (2 females, OPC). Dibër district, Lurë area, Fushë Lurë, brook in the village, N41 ${ }^{\circ} 48.719^{\prime}$ E20 ${ }^{\circ} 12.823$ ', 1075 m, 08.X.2012, leg. P. Juhász, T. Kovács, D. Murányi, G. Puskás
(1 female, OPC). Korçë district, Vallamarë Mts, open brook above Lower Lenija Lake, SE of Vallamarë Peak, N4047.374' E20²8.250', 2100 m, 10.X.2013, P. Juhász, T. Kovács, D. Murányi, G. Puskás, (1 female, OPC). Tepelenë district, Kurveleshi area, Progonat, Gurrit Stream spring area, E of the village, $\mathrm{N} 40^{\circ} 12.629^{\prime} \mathrm{E}^{\circ} 9^{\circ} 58.237^{\prime}$, 1045m, 14.X.2013, leg. P.Juhász, T. Kovács, D. Murányi, G.Puskás, (1 male, OPC). Delvina Region, Syri i Kalter near Bistrica Village, $155 \mathrm{~m}$, N3955'23"; E020¹1'30" 23.X.2017, leg. S. Beshkov \& A. Nahirnic (3 males, 4 females; OPC). Macedonia, Pelagonia region, Pelister Mts, Nižepole, open brook at the ski station, $\mathrm{N} 40^{\circ}$ 58.787' E2 $1^{\circ} 15.218^{\prime}, 1375 \mathrm{~m}, 2 . X .2013$, leg. T. Kovács, D. Murányi, (2 females, OPC).

Diagnosis. Dorsal protuberance on the aedeagus is absent. Apical tuft of fine spinules on the tip of the apical lamellae is present. Paramere shaft is an elongated rod, not vertically flattened plate-like and not enlarging basad. Dorsal shape of paramere shaft is straight, not sigmoid. The 
apical spine is extremely curving upward and anterad accompanied and masked by a tuft of subapical spine on the dorsum.

\section{Potamophylax ibericus Szczesny, 1994 stat. nov.}

Potamophylax cingulatus ibericus Szczesny, 1994 (partim) in Moretti et al. 1994: 99, "Holotypus: Oे $^{-1}$ (Coll. Szczesny), Spanien, Sierra de Montseny, leg. H. Malicky." Diagnosis: In der Mitte des Aedoeagus keine dorsale Protuberanz; distales Ende zugespitzt (Abb. 52, 53). Der membranöse, faltige Dorsalwulst mit dem phallotremal ist auffallend laggestrekt (Lateralansicht, Abb. 52). Parameren auf ganzer Länge mit zahlreichen kurzen Borsten besetzt (Abb. 53), einige von ihnen sind distal in charakteristischer Weise gespalten (Abb. 54, 55); 1-2 additionelle längere Apicalborsten vorhanden.”

Potamophylax ibericus Szczesny, 1994. Present study: based on the theoretical consideration of the unified phylogenetic specie concept as well as on the stability of recorded divergences of the speciation traits in reproductive barriers building we have changed its taxonomic status to an incipient sibling species. stat. nov.

Material examined. "Holotypus: $\hat{\jmath}$ (Coll. Szczesny), Spanien, Sierra de Montseny, leg. H. Malicky." (1 male, NHM-ISEA).

Diagnosis. As already Szczesny (1990) has recognised the fine structure of the phallic organ is characterized by "spineless lateral edges of the apex of the phallus and the parameres are covered with hairs."

Re-diagnosis. Dorsal protuberance on the aedeagus is absent. Apical tuft of fine spinules on the tip of the apical lamellae is absent. Paramere shaft is an elongated rod, not vertically flattened plate-like and not enlarging basad. Dorsal shape of paramere shaft is straight, not sigmoid. The apical spine is slightly curving upward and more anterad accompanied by 1-2 additional spines. Almost the entire dorsum of the paramere shaft is packed by 8-9 short frequently bifid spines.

\section{Potamophylax inermis Moretti \& Cianficconi, 1994}

Potamophylax inermis Moretti \& Cianficconi, 1994 in Moretti et al. 1994: 94, "Holotypus, ô (Coll. Mo- retti), Italien, Apennin, Region Lazio, Fonte Velino, Rieti, 400 m, 29. IX. 1969, leg. Mattioni. Diagnose: "Flügel einfarbig, ohne Punkte. Parameren ohne zusätzliche Borsten. Apikalstacheln am aedoeagus fehlen (Abb. 16). Die Art steht aufgrund der gleichgestalteten, jedoch nicht sklerotisierten Ventralfalte $P$. goulandriorum verwandtschaftlich nahe; diese beiden Arten können al seine Untergruppe des cingulatus-Komplexes aufgefaßt warden."

Material examined. Italy, Lazio (Rieti), Castel S. Angelo, Vasche Prato Grande, UTM-33T0336136-4692744, 418 m, 6.VI.2013, leg. R. Fabbri (6 males, 2 females; OPC).

Diagnosis. Dorsal protuberance on the aedeagus is absent. Apical tuft of fine spinules on the tip of the apical lamellae is absent. Paramere shaft is an elongated rod, not vertically flattened platelike and not enlarging basad. Dorsal shape of paramere shaft is straight, not sigmoid. The main apical spine curving slightly upward and mesad in lateral view and no additional spines are present. There are no spines present along the paramere shaft.

\section{Potamophylax latipennis (Curtis, 1934)}

Limnephilus latipennis Curtis, 1834: 125, "19 lines: pale ochreous, silky; superior wings with edges of the nervures very pale fuscous, forming indistinct rays towards the apex."

Limnephilus stellatus Curtis, 1834: 125, "16 to 17 lines: superior wings very pubescent fuscous ochre, with pale lines at base and centre of the discoidal nervures, 2 or 3 small spots at the base, a bilobed one near the centre, 2 dots by the transverse nervures and a curved series of pale streaks beyond them; inferior wings fuscous ochreous, very pale at the base."

Stenophylax stellatus Curtis, 1834: McLachlan 1875: 128-130, "Superior appendages ordinarily not projecting beyond the margin of the segment; internally they are seen to be formed of two obtuse concave lobes of equal lengths, the inner rather the smaller, crenulated and black on its edge. Intermediate appendages elongately triangular or lanceolate, acute, the tips black" "Very widely distributed, but probably more abundant in the north of Europe; somewhat autumnal in its habit, yet it occurs also in summer." 
Limnephilus stellatus Curtis, 1834: Neboiss 1963: 605, 621, synonymysed with Potamophylax latipennis (Curtis, 1834).

Material examined. Albania, North Albanian Alps, Ceram, 1200-1300 m, 29-30.VII.2016, leg. Z. Varga (1 male, OPC). Andora, Llorts, $1429 \mathrm{~m}$, 10.X.1988, leg. J. Dantart (2 males, 1 female; OPC). Austria, Langau, Ybbs, 19-22.VII.1984 leg. Á. Uherkovich (1 male, OPC). BosniaHerzegovina, Sutjeska National Park, Klobucarika, 3.IX,1988 light leg. J. Oláh (1 male, 1 female; OPC). Bulgaria, Vitosha Mts., Kladnitsa, Sv. Nikola, Tanchovitsa, N42³4'02.9', E2311' 41.4", 1100 m, 3.X.2011, light, leg. Á. Ecsedi, T. Kovács, \& G. Puskás, $(4 \hat{\jmath}, 4+$, OPC). Bulgaria, Stara Planina, Mts Vârbishka, above Medven, N42 50 '32.6” E263' 57.0”, 420m - singled, beaten, waternet and light trap, in and around a stream and a forest above (alder grove and dry oak forest on sandstone), 4-5.IX.2005, leg. D. Murányi (3 males, 1 females, HNHM). Bulgaria: Rhodopi, Yadenitza above Golyamo Belovo, $1167 \mathrm{~m}$, N42 06 '15" E235'11", 6.IX.2012, at lamps, light traps leg. S. Beshkov \& M. Beshkova, (28 males, 3 females, NMNHS; 22 males, 12 females, OPC). Czech Republic, N Bohemia, Bohemian Switzerland NP, Křinice river, Zadní Jetřichovice, VI.2010, Malaise trap leg. M. Trýzna (1 male, OPC; 1 male, 1 female, NMPC). Czech Republic, W Bohemia, Krušné hory Mts, Hluboký potok brook nr. Dolní Nivy, $50^{\circ} 14^{\prime} 24^{\prime \prime} \mathrm{N} 12^{\circ} 36^{\prime} 24^{\prime \prime} \mathrm{E}$; 31. VIII. 2015, at light leg. J. Šumpich (1 male, 2 females, OPC; 1 males, 5 females, NMPC). England, Lancashire, Nelson, Admergill stream, Blacks, 18.IX.1975, leg. A. Brindle (1 male, 1 female; MMUE). England, Lancashire, Colne, Slipper Hill Reservoir, 27.VIII.1980 at light leg. A. Brindle (2 males, 1 female; MMUE). France, Ardennes Department, Autrecourt, Fontaine de Brouhan, 208 m, 22.VIII.2013, leg. G. Coppa (1 male, OPC). Kosovo, Letnicë, Viti Municipality, $659 \mathrm{~m}$, N42 ${ }^{\circ} 16.876$ ', E021 $28.108 ', 12 . X .2017$, leg. B. Emërllahu and H. Ibrahimi (1 male, OPC). Macedonia, Pelister Mts. Planinarski Dom "Shiroka", $1955 \mathrm{~m}, \mathrm{~N} 41^{\circ} 00^{\prime}$ 17" E2110' 07”, 6.VIII. 2016, leg. S. Beshkov \& A. Nahirnic (1 male,
OPC). Norway, Hedmark, Stol-Elvdal Rasta, Fv 606 ved Glomma, $61.3992540^{\circ} \mathrm{N} 11.1440100^{\circ} \mathrm{E}$, 29-31.II.2016, light trap leg. T. Andersen \& L. Hagenlund (Hedmarkprosjektet) (3 males, OPC). Norway, Hedmark, Engerdal, Jonasvollen, $62.231437^{\circ} \mathrm{N} 11.874940^{\circ} \mathrm{E}, 24$. VII. 2016, ligh trap leg. T. Andersen \& L. Hagenlund (Hedmarkprosjektet) (3 males, OPC). Norway, Hedmark, Engerdal, Åsen, $61.885861^{\circ} \mathrm{N} 11.782833^{\circ} \mathrm{E}, 2 . \mathrm{IX}$. 2016, Malaise trap leg. Rikmyrsprosjectet (4 females, OPC). Romania, Romania: Apuseni Mts, Arieseni, Virtop Pass, 27.VII.2007, leg. M. Bálint (1 male, OPC). Romania, Apuseni Mts, Valul Crisul, Misid, 17.IX.2014, leg. Cs. Balogh (12 males, 69 females; OPC). Jud Hargitha, Sâncrăieni, Valea Mare, 20-21.IX.1993. light trap, leg. L. Újvárosi (1 male, OPC). Romania, Retezat Mts., Bucura stream, below Bucura lake, 2070m, N4521'27,872” E2252’28,695”, 8.VIII.2015, light leg. J. Kecskés, \& Zs. Pap (2 males, OPC). Romania, Hargita Mts, stream at Zetelaka, 7.IX. 2017, light leg. J. Oláh jr. (3 males, OPC). Romania, Radnei Mts. Complex Borsa, Viseau stream, 26.IX.2014, light trap leg. J. Oláh \& Cs. Balogh (1 male, OPC). Romania, Muntii CodruMoma, Moneasa, stream Moneasa, 31.VIII.2012, light leg. Cs. Deák (4 males, 5 females, OPC). Romania, Muntii Lezerului, 1050 m, 45.45 25.02, 4.VIII.2006, leg. M. Bálint (2 males, OPC). Romania, Sibiu county, Făgăraş Mts, Cârțişoara, Bâlea Stream along road No.7C, at Rece Motel, 29.VIII.2012 leg. T. Kovács, D. Murányi, J. Oláh (2 males, 1 female; OPC). Romania, Maramures county, Maramaros Mts. Frumuseaua stream, 764 m, N47 52'43' E24 ${ }^{\circ} 18^{\prime} 22^{\prime}$ ', 7.VIII.2012, light trap leg. J. Oláh \& L. Szél (1 male, 2 females; OPC). Romania, Retezat Mts. Cerna Valley, 23 $\mathrm{km}$ upstream Herculane, Forest Range, N45 $02^{\prime}$ 30” E21 '50’35”, 20-21.VI.2012, leg C. Ciubuc (3 males, CCPC). Romania, Anina Mts. Miniş, downstream Plopa Cave, N4501'50.4" E21 ${ }^{\circ} 50^{\prime}$ 35", 21-2.VI.2012, leg C. Ciubuc (6 males, 1 female; CCPC). Romania, Maramures Mts. Valley Catarama, left tributary of Vaser, $47^{\circ} 44^{\prime}$ 40" 2448'07", 22-23.VI.2012, leg C. Ciubuc (8 males, 3 females; CCPC). Romanaia, Făgăraş Mts. Valley Capra, (V. Argeş), 45 35'05.7' 243'28.0”, 5-6.VIII.2012, leg C. Ciubuc (5 
males, 5 females; CCPC). Romania, Apuseni Mts. Gârda Seacă, Gârda de Sus, Dobra House, N4628'16" E2150'35", 30-31.VII.2006, leg C. Ciubuc (38 males, 47 females; CCPC). Romania, Apuseni Mts. Someşul Cald, at Obârşie (upstream Ic Ponor), 46³7’40” 21 ${ }^{\circ} 50^{\prime} 35^{\prime}$, , 21-22.VI.2012, leg C. Ciubuc (9 males, 6 females; CCPC). Romania, Retezat Mts. Gura Zlata Seismic Station, N4523'29.38' E22 $46^{\prime}$ ' 16.64', 20-1.VI. 2012, leg C. Ciubuc (4 males, 1 female; CCPC). Slovakia, West Tatra, Bela Reka, 3.VII.1976, light leg. Nagy (2 males, OPC). Slovakia, Pavčina Lehota, 500 m, 7-8.VIII.1989, leg. L. Ábrahám (1 male, OPC). Serbia, Tzaribrod distr. Erma Gorge near Poganovo 577m, N42 ${ }^{\circ} 57^{\prime} 575^{\prime \prime}$ E22 32 '14", 22.X.2013, leg. S. Beshkov (5 males, OPC). Ukraine, Bieszczady Mts (Besszádok), Ung National Park, above Lubnya (Kiesvölgy), N 4902'13.90” E2242' 59.75”, 579 m, singled, 20. IX.2013, leg. J. Oláh, Cs. Balogh, Cs. Deák \& I. Meszesán (1 female; OPC).

Diagnosis. The setose outer lobe of the cerci is less produced compared to all the other species in the species group except $P$. fesus sp. nov. Dorsal protuberance on the aedeagus is absent. Apical tuft of fine spinules on the tip of the apical lamellae is present. Paramere shaft is an elongated rod, not vertically flattened plate-like and not enlarging basad. Dorsal shape of paramere shaft is sigmoid, not straight. The apical spine is slightly curving upward and in a more anterad position is accompanied by one small subapical spine. 5-6 spines present on the ventrum of the middle section of the paramere shaft.

\section{Potamophylax portugalicus Oláh \& Szczesny, sp. nov.}

(Figures 5-8)

Potamophylax cingulatus ibericus Szczesny, 1994 (partim) in Moretti et al. 1994: 99, "Paratypen: 10 (Coll. SzCZESNY), Portugal, Serra da Gerês, 8.X. 1975, leg. Da Terra; 4đ̋ (SMF Tri 11754-Tri 11557, ex Coll. Döhler), Portugal, Serra da Estrêla, Penhas Dourads, 1500 m, 3-9.VII.1955, leg. H. Noack; $1{ }^{\uparrow}$ (SMF Tri 11758, ex Coll. Döhler),
Portugal, Serra da Estrêla, Manteigas, 850 m, 25. VIII.-2.IX.1955, leg. H. Noack.” Misidentification!

Material examined. Holotype: "Paratypen: $10^{\lambda}$ (Coll. Szczesny), Portugal, Serra da Gerês, 8. X. 1975, leg. Da Terra". (1 male, NHM-ISEA).

Paratypes (not examined): 4ภํ (SMF Tri 11754-Tri 11557, ex Coll. Döhler), Portugal, Serra da Estrêla, Penhas Dourads, 1500 m, 39.VII.1955, leg. H. Noack; $1 \overbrace{}^{\lambda}$ (SMF Tri 11758, ex Coll. Döhler), Portugal, Serra da Estrêla, Manteigas, 850 m, 25. VIII.-2.IX.1955, leg. H. Noack."

Diagnosis. The holotype of this new species was collected in Portugal, determined and selected as paratype of $P$. ibericus collected from Spain (Szczesny 1994). Dorsal protuberance on the aedeagus is absent. Apical tuft of fine spinules on the tip of the apical lamellae is absent. Paramere shaft is an elongated rod, not vertically flattened plate-like and not enlarging basad. Dorsal shape of paramere shaft is straight, not sigmoid. The apical spine is slightly curving upward with a single accompanying subapical spine. There are three slender long spines on the dorsum of the parameres.

$P$. portugalicus sp. nov. is most close to $P$. ibericus Szczesny, but differs by having differently shaped periphallic organs: (1) on the bilobed cerci both the setose outer and the heavily sclerotized inner lobe diverged: outer lobe longer, inner lobe shorter and more serrated; (2) the dorsal branch of the paraproct slender and longer; (3) the ventral profile of the gonopod apical region widened apicad, not parallel-sided. However, there is no population sample to examine the variability ranges of these neutral traits more exposed to stochastic processes, therefore further sampling and examination are required to differentiate reliably the two species based only on the periphallic organs. There are however stable divergences in the adaptive speciation traits: (1) endophallic membrane around the phallotremal sclerotized opening discernible in lateral view is much shorter; (2) the spine pattern along the dorsum of the paramere shaft is clearly different, 


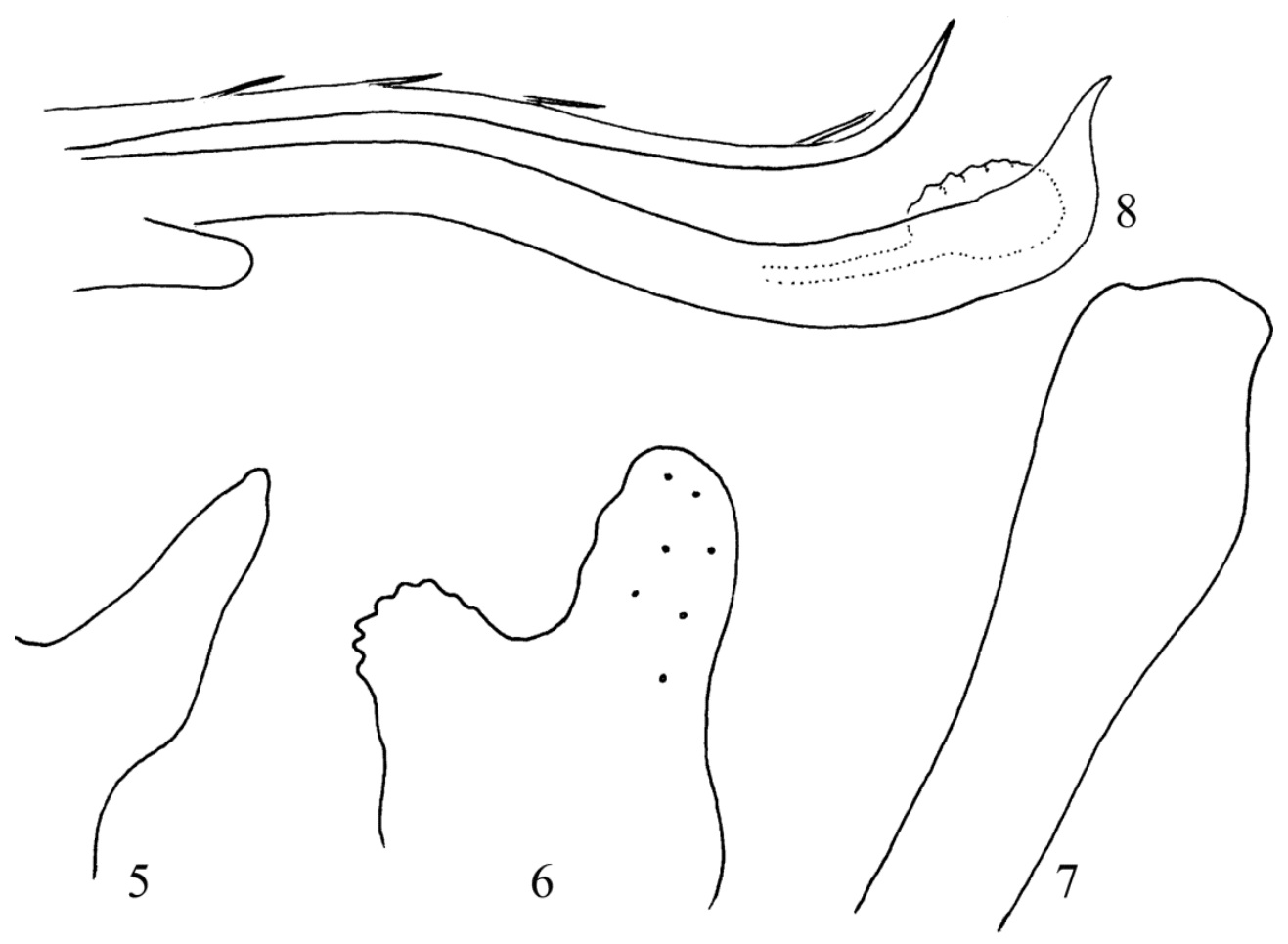

Figures 5-8. Potamophylax portugalicus Olah \& Szczesny, sp. nov. Holotype: $5=$ dorsal branch of the paraproct in left lateral view, $6=$ cercus in perpendicular dorsal view, $7=$ apical section of left gonopod in perpendicular ventral view, $8=$ paramere and aedeagus of phallic organ in left lateral view.

there are only $2-3$ spines present, not $10-11$ and the spines are slender and longer, not short stout with frequently bifid apex.

Etymology. portugalicus, named for the country in which the types were collected.

\section{Potamophylax seprus Oláh, Lodovici \& Valle, 2011}

Potamophylax seprus Oláh, Lodovici \& Valle, 2011, "Holotype male. Albania, Skrapar county, Tomor Mts, Kulmak Pass, mountain grassland near the bektashi teqe, $\mathrm{N} 40^{\circ} 37.116^{\prime} \mathrm{E} 20^{\circ} 11.945^{\prime}, 1485 \mathrm{~m}$, 23.VIII.2006, leg. Z. Fehér, A. Hunyadi, T. Huszár \& D. Murányi, coll. Hungarian natural History Museum, Budapest." "Diagnosis. The species group of Potamophylax latipennis has bilobed cerci with synapomorphy of the strongly sclerotized inner or mesal cercal lobe. The cercal lateral angle is produced into the moderately sclerotized outer or lateral setose lobe and the cercal mesal angle is produced into the strongly sclerotized inner or mesal rounded and serrate lobe. Four species belong to this species cluster: Potamophylax latipennis (Curtis, 1934), Potamophylax cingulatus (Stephens, 1937), Potamophylax goulandriorum Malicky, 1974, Potamophylax seprus n. sp. Potamophylax cingulatus is a highly polymorphous species with several described subspecies. The separation of subspecies was based primarily on the phallicata apex and on the spine structure of the parameses. However, this polymorphous species exhibits more variability than established by the described subspecies (Malicky 2010, personal communication). Weekly sclerotized and unarmed cerci are considered plesiomorphic condition in Lepidoptera and most Trichoptera (Vshivkova, 2007). Strongly sclerotized inner areas of cerci is a synapomorphy for some lineages of Chaetopterygini and Limnephilini. Strongly sclerotized inner lobe of cerci with irregular serrate dorsal and mesal margins or edges seems synapomorphy for the Potamophylax latipennis species group. Potamophylax seprus belongs to $P$. latipennis species group and most resembles to Potamophylax goulandriorum Malicky, 1974 described from 
Greece. Easily distinguishable in apical view either from $P$. latipennis by the shorter cercal mesal lobe or from $P$. cingulatus by the right angle of the laterad curving apical third of the inner branch of paraproct. $P$. goulandriorum has also shorter cercal mesal lobe and right angle on the paraproct. However, $P$. seprus n. sp. differs from $P$. goulandriorum very clearly by the high phallicata and by the vertically flattened very high plate-like paramere shaft as well as by the spine bunch on the parameres. There are several dimensional and proportional differences in the shape of segment IX, cerci, paraproct and gonopod, but having only a single male specimens its variability is unknown."

Material examined. Holotype male. Albania, Skrapar county, Tomor Mts, Kulmak Pass, mountain grassland near the bektashi teqe, $\mathrm{N}^{\circ} 0^{\circ} 37.116^{\prime}$ E20 ${ }^{\circ} 11.945$ ', 1485m, 23.VIII.2006, leg. Z. Fehér, A. Hunyadi, T. Huszár \& D. Murányi, (1 male, HNHM).

Diagnosis. Dorsal protuberance on the aedeagus is absent. Apical tuft of fine spinules on the tip of the apical lamellae is modified into a pointed mesad curving spine-like structure. Paramere shaft is vertically flattened plate-like. Apical spine or rather exact to name it as the leading main spine is curving upward and anterad and accompanied by special, very characteristic pattern of variously curving and variously sized subapical spines.

Potamophylax spinulifer Moretti, 1994 stat. nov.

Potamophylax gambaricus spinulifer Moretti, 1994 in Moretti et al. 1994: 96-98, "Holotypus: ô (in Coll. Moretti), Italien, Abruzzen, Fonte Romana, M. Maiella, L'Aquilla, 1300 m, 16.VII.1971. leg. Di Gregorio. Paratypen: Mehrere $\widehat{\partial} \widehat{\partial}$, Coll. Moretti und Coll. Szczesny, verschiedene Fundorte in Italien: Abruzzen (mehrere Quellen), Emilia Romagna (Fluß Tevere), Toscana (Alpi Apuane), Marche (an mehreren Stellen), 1971-1972 leg."

"Diagnose: Flügelfärbung einheitlich oder mit einigen Flechen. Ventralfalte langgestreckt und dadurch eine tiefe Tasche bildend (Abb. 28). Aedoeagusspitzen von dorsal betrachtet deutlich gegabelt, mit zahlreichen Apikalstacheln, die in einer membranösen Zone stehen (Abb. 28, 31, 32),
Aedoeagusschaft besonders im ventro-proximalen Abschnitt leicht gefaltet. Parameren mit langer, mediad leicht gebogener Endborste und mit meist 5 additionalen präapikalen Borsten von variabler Länge, die am äußeren, latero-ventralen Rand stehen (Abb. 29, 30)." Das taxon zeigt genitalmorphologische ähnlichkeiten mit dem bislang nur auf dem Südbalkan nachgewiesenen goulandriorum, dem im Süden Italiens und auf Sizilien verbreiteten gambaricus sowie mit cingulatus alpi$n u s$ aus dem Alpengebiet. Die typischen schwach gebogenen, langen Endborsten und die Borstenbüschel der Parameren stimmen allerdings recht gut in Form und Anordnung mit den entsprechenden Strukturen bei gambaricus, nicht aber bei c. alpinus überein; goulandriorum wiederum scheint ausschließlich auf der südlichen Balkanhalbinsel vorzukommen. Aus diesen Gründen fassen wir die geographisch zwischen gambaricus und c. alpinus intermediär verbreitete spinulifer als Subspezies von gambaricus auf."

Potamophylax spinulifer Moretti, 1994. Present study: based on the theoretical consideration of the unified phylogenetic species concept as well as on the stability of recorded divergences of the speciation traits in reproductive barriers building we have changed its taxonomic status to an incipient sibling species. stat. nov.

Material examined. Italy, Toscana, Marradi (FI), Badian Valle, 430 m, 28.IX.1998, leg. A. Usvelli (6 males, 3 females; OPC).

Diagnosis. Dorsal protuberance on the aedeagus is absent. Apical tuft of fine spinules on the tip of the apical lamellae is present. Paramere shaft is slightly and gradually enlarging basad. The single apical spine is curving upward and mesad and accompanied by a subapical tuft of 5-6 spines with different length.

\section{Potamophylax transalpinus Oláh \& Coppa sp. nov.}

(Figures 9-12)

Material examined. Holotype: France, AlpesMaritimes Department, Belvédère, La Gordolasque, 12.VII.2012, leg. G. Coppa (1 male, CPC). Allotype: same as holotype (1 female, CPC). Paratypes: France, Alpes-Maritimes De- 


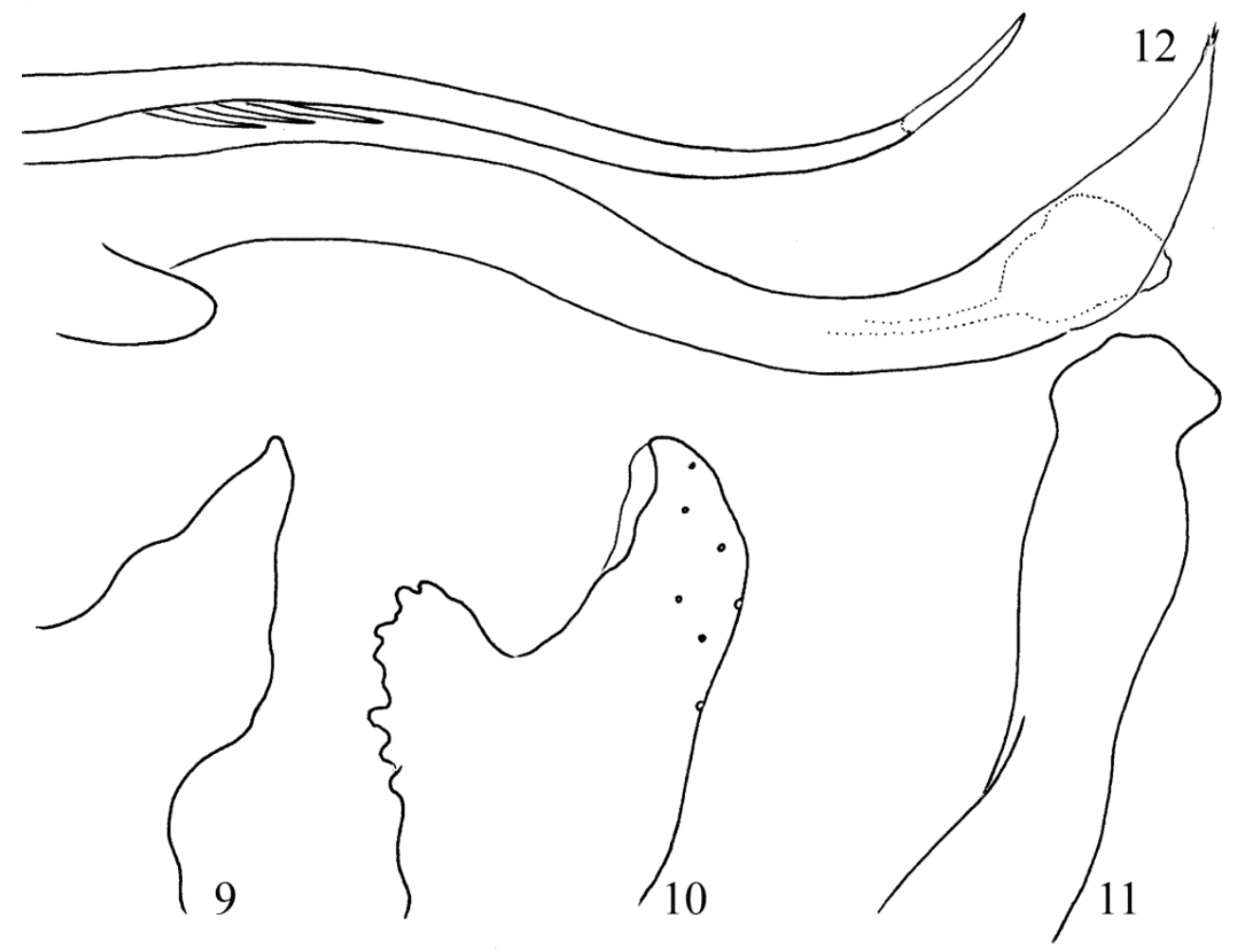

Figures 9-12. Potamophylax transalpinus Olah \& Coppa, sp. nov. Holotype: $9=$ dorsal branch of the paraproct in left lateral view, $10=$ cercus in perpendicular dorsal view, $11=$ apical section of left gonopod in perpendicular ventral view, $12=$ paramere and aedeagus of phallic organ in left lateral view.

partment, Belvédère, La Grange du Colonel, 8. VII. 2012, leg. G. Coppa (1 male, CPC). France, Alpes-Maritimes Department, Tende, sur la Roya au Niveau du Tunnel, 1300 m, 31.VIII.2010, leg. G. Coppa (1 male, OPC). France, Alpes-Maritimes Department, Malaussene, Source de la Gorgette, 1300 m, 3.X.2012, leg. G. Coppa (1 male, OPC). France, Alpes-Maritimes Department, Isola, Col de la Lombarde, 2350 m, 30.VIII.2011, leg. G. Coppa (3 males, OPC). France, AlpesMaritimes Department, Saint-Etienne-de-Tinée, Bourquel pré du Loup, 1050 m, 8.IX.2011, leg. G. Coppa (2 females, CPC). France, Hautes-Alpes Department, Nevache, Marais de Nevache Ville Basse, 1600 m, 5.VIII.2012, leg. G. Coppa (1 male, OPC). France, Hautes-Alpes Department, Agnières-en-Devolluy, La Ribière, 1310 m, 20. VIII.2009, leg. G. Coppa (3 male, 2 females; OPC). France, Ain Department, Chaley, $\mathrm{Ru}$ de Merdaret Amont du Moulin, 6.X.2011, leg. G. Coppa (1 male, OPC).
Diagnosis. The setose outer lobe of the bilobed cerci is much longer than the heavily sclerotized and pegged inner lobe. The dorsal branch of the paraproct is rather robust triangular in lateral view. Dorsal protuberance on the aedeagus is absent. Apical lamellae of the aedeagus are gradually and regularly pointing apicad. Apical tuft of fine spinules on the tip of the apical lamellae is present. Paramere shaft is an elongated rod, not vertically flattened plate-like and not enlarging basad. Dorsal shape of paramere shaft is straight, not sigmoid. The lateral shape is slightly sigmoid. The apical spine is straight without any accompanied additional smaller spines. 3-4 spines are present on the ventrum of the basal section of the paramere shaft.

The new species is most close to and diverged from $P$. alpinus, but differs by having the membranous dorsal protuberance on the middle of the aedeagus shaft lost, the lateral shape of the apical 
lamellae of the aedeagus differently shaped in lateral view as well as the dorsal shape of the paramere shaft is straight, not sigmoid, the apical spine has no additional adhering smaller spines and the spines on the basal half is located ventrad, not dorsad.

Contact population. Paratypes collected in Belvedere and in Malaussene have an additional small adhering spine accompanying the apical spine of the paramere.

Etymology. transalpinus, "over the Alps" with reference to the known distribution records of the new species in the Western, French region of the Alps Mts.

Acknowledgements - We appreciate the material provided to our studies by Pavel Chvojka, National Museum, Prague, Czech Republic; by the Museo Civico di Scienze Naturali "E. Caffi", Bergamo, Italy and we are especially thankful to our cooperating colleagues Director Marco Valle and Omar Lodovici for their permanent support. Valuable materials have been provided and our studies supported by Dmitri Logunov, The Manchester Museum, University of Manchester.

\section{REFERENCES}

ANDREASEN, R.O. (1998): A new perspective on the race debate. British Journal for the Philosophy of Science, 49: 199-225. doi: 10.1093/bjps/49.2.199

Avise, J.C. \& WALKER, D. (1999): Species realities and numbers in sexual vertebrates: perspectives from an asexually transmitted genome. Proceedings of the National Academy of Sciences USA, 96: 992995. doi: $10.1073 /$ pnas.96.3.992

Barbujani, G., Ghirotto, S. \& TASsi, F. (2013): Nine things to remember about human genome diversity. Tissue Antigens, 82: 155-164. doi: $\underline{10.1111 / \tan .12165}$

BARRAClOUGH, T.G. (2010): Evolving entities: towards a unified framework for understanding diversity at the species and higher levels. Philosophical Transactions of the Royal Society B, 365: 18011813. doi: $10.1098 / \mathrm{rstb} .2009 .0276$

Botnariuc, N. (1967): Principii de biologie generală. Editura Academiei Republicii Socialiste Romania, Bucuresti, 142 pp.
BURKHEAD, N.M. \& WILlIAMS, J.D. (1991): An intergeneric hybrid of a native minnow, the Golden Shiner, and an exotic minnow, the Rudd. Transactions of the American Fisheries Society, 120: 781-795. doi: 10.1577/1548-8659(1991)120<0781:AIHOAN>2.3.CO;2

CICERO, C. (2010): The significance of subspecies: a case study of Sage Sparrows (Emberizidae, Amphispiza belli). Ornithological Monographs, 67: 103113.

Claridge, M.F. (2010): Species are real biological entities. In. AYALA, F.J. \& ARP, R. (Eds.) Contemporary debates in philosophy of biology. Blackwell Publishing Ltd, p. 91-109. doi: $10.1002 / 9781444314922 . c h 5$

CRACRAFT, J. (1987): Species concepts and the ontology of evolution. Biology and Philosophy, 2: 329346.

CURTIS, J. (1834): Descriptions of some nondescript British species of May-flies of Anglers. The London and Edingburgh Philosophical Magazine and Journal of Science, (3) 4(20): 120-125.

DARWIN, C. (1844-1846): Letters. In. BURKHARDT, F. $\&$ SMITH, S. (Eds.) The correspondence of Darwin. vol. 3 (1844-1846). Cambridge University Press, Cambridge, 1988, 576 pp.

DEANS, A.R. et al. (with 72 co-authors) (2015): Finding our way through phenotypes. PLOS Biology, 13(1): e1002033. doi: 10.1371 /journal.pbio. 1002033

DiAZ-LEON, E. (2012): Social kinds, conceptual analysis, and the operative concept: a reply to Haslanger. Humana Mente Journal of Philosophical Studies, 22: 57-74.

DOBZHANSKY, T. (1935). A critique of the species concept in biology. Philosophy of Science, 2: 344-355. doi: $10.1086 / 286379$

DoBZHANSKY, T. 1937. Genetics and the origin of species. New York.

DOBZHANSKY, T. (1963): Genetic entities in hominid evolution. In. WASHBURN, S.L. (Ed.) Classification and human evolution. Chicago, Aldine, p. 347-362.

DoBZHANSKy, T. \& SPASSKY, B. (1959): Drosophila paulistorum, a cluster of species in statu nascendi. Proceedings of the National Academy of Sciences, 45: 419-428.

EDWARDS, A.W.F. (2003): Human genetic diversity: Lewontin's fallacy. BioEssays, 25: 798-801. doi: $\underline{10.1002 / \text { bies. } 10315}$ 
ERESHEFSKY, M. (2010): Darwin's solution to the species problem. Synthese, 175: 405-425. doi: $10.1007 / \mathrm{s} 11229-009-9538-4$

FITZPATRICK, J.W. (2010): Subspecies are for convenience. Ornithological Monographs, 67: 54-61. doi: $10.1525 / \mathrm{om} .2010 .67 .1 .54$

GANETT, L. (2013): Theodosius Dobzhansky and the genetic race concept. Studies in History and Philosophy of Biological and Biomedical Sciences, 44(3): 250-261. doi: 10.1016/ i.shpsc.2013.04.009

GARRETT, D.L. (2005): A new intergeneric hybrid flatfish (Pleuronectiformes: Pleuronectidae) from $\mathrm{Pu}-$ get Sound and adjacent waters. Copeia, 2005: 673677. doi: 10.1643/CI-04-344R

GLASGOW, J. \& WoODWARD, J.M. (2015): Basic racial realism. Journal of the American Philosophical Association, 1(3): 449-466. doi: 10.1017/apa.2015.7

GrAVES, G.R. (2007): Diagnoses of hybrid hummingbirds (Aves: Trochilidae). 15. A new intergeneric hybrid (Hylocharis leucotis $\times$ Selasphorus platycercus) from the Huachuca Mountains, southeastern Arizona. Proceedings of the Biological Society of Washington, 120: 99-105. doi: 10.2988/0006-324X(2007)120[99:DOHHAT]2.0.CO;2

GRAVES, G.R., \& ZUSI, R.L. (1990): An intergeneric hybrid hummingbird (Heliodoxa leadbeateri $\times$ Heliangelus amethysticollis) from northern Colombia. The Condor, 92: 754-760. doi: 10.2307/1368695

HASLAM, N.O. (1998): Natural kinds, human kinds, and essentialism. Social Research, 65(32): 291314.

HASlanger, S. (2006): Philosophical analysis and social kinds. I. What good are our intuitions? Proceedings of the Aristotelian Society Supplement, 80(1): 89-118. doi: 10.1111/j.1467-8349.2006.00139.x

HAUSDORF, B. (2011): Progress toward a general species concept. Evolution, 65(4): 923-931. doi: $10.1111 / \mathrm{j} .1558-5646.2011 .01231 . \mathrm{x}$

Hendry, A.P., VAmosi, S.M., LATham S.J., HeILBUTH, J.C. \& DAY, T. (2000): Questioning species realities. Conservation Genetics, 1: 67-76. doi: 10.1023/A:1010133721121

HeNNIG, W. (1950). Grundzüge einer Theorie der phylogenetischen Systematik. Deutscher Zentralverlag, Berlin, $370 \mathrm{pp}$.

Hennig, W. (1966): Phylogenetic Systematics. University of Illinois Press, Urbana, 263 pp.
HEY, J. (2001): The mind of the species problem. Trends in Ecology and Evolution, 16(7): 326-329. doi: $10.1016 / \mathrm{S} 0169-5347(01) 02145-0$

Hey, J., Waples, R.S., Arnold, M.L., Butlin, R.K. \& HARRISON, R.G. (2003): Understanding and confronting species uncertainty in biology and conservation. Trends in Ecology and Evolution, 18(11): 597-603. doi: 10.1016/i.tree.2003.08.014

HUNTER, P. (2006): Defining species. European Molecular Biology Organization Reports, 7(8): 763766. doi: 1038/sj.embor. 7400763

HuXley, J. (1940): The new systematics. Oxford University Press, $583 \mathrm{pp}$.

IsAAC, N.J.B., MAllet, J. \& MACE, G. M. (2004): Taxonomic inflation: its influence on macroecology and conservation. Trends in Ecology and Evolution, 19(9): 464-469. doi: 10.1016/j.tree.2004.06.004

JAMES, M. (2017) Race. In. ZALTA, E.N. (Ed.) Stanford Encyclopedia of Philosophy (Spring 2017 Edition). Available at: https://plato.stanford.edu/ar chives/spr2017/entries/race/ (Accessed 02.03.2018)

JARVIS, E.D. (2014): Whole-genome analyses resolve early branches in the tree of life of modern birds. Science, 346(6215): 1320-1331. doi: $10.1126 /$ science. 1253451

Jolly, C.J., Woolley-Barker, T., Beyene, S., DisoTELL, T.R. \& PHILLIPS-CONROY, J.E. (1997): Intergeneric hybrid baboons. International Journal of Primatology, 18: 597-627. doi: $10.1023 / \mathrm{A}: 1026367307470$

JoRDE, L.B. \& WoODING, S.P. (2004): Genetic variation and 'race'. Nature Genetics, 36(11): S28-S33. doi: $10.1038 / \mathrm{ng} 1435$

KITCHER, P. (2007): Does 'race' have a future? Philosophy and Public Affairs, 35(4): 293-317. doi: 10.1111/j.1088-4963.2007.00115.x

KomzaK, P. \& ChvojKA, P. (2012): Caddis flies (Trichoptera) of the Bílé Karpaty protected landscape area and biosphere reserve (Czech Republic). Acta Musei Moraviae, Scientiae biologicae (Brno,) 96(2)2011: 697-761.

LARsen, B.B., Miller, E.C., Rhodes, M.K. \& Wiens, J.J. (2017): Inordinate Fondness Multiplied and Redistributed: the Number of Species on Earth and the New Pie of Life. The Quaterly Review of Biology, 92(3): 229-265. doi: 10.1086/693564

LAUDAN, L. (1981): The pseudo-science of science. Philosophy of the Social Science, 11: 173-198. doi: 10.1007/978-94-015-7688-8_2 
LeClere, J.B., HoAglund, E.B., Scharosch, J., SMITH, C.E. \& GAMBLE, T. (2012): Two Naturally Occurring Intergeneric Hybrid Snakes (Pituophis catenifer sayi $\times$ Pantherophis vulpinus; Lampropeltini, Squamata) from the Midwestern United States. Journal of Herpetology, 46(2): 257-262. doi: $\underline{10.1670 / 10-260}$

LEDFORD, H. (2008): Language: Disputed definitions. Nature, 455: 1023-1028. doi: 10.1038/4551023a

LEE, M.S.Y. (2016): Count cryptic species in biodiversity tally. Nature, 534: 621. doi: 10.1038/534621a

LEWONTINE, R.C. (1972): The apportionment of human diversity. Evolutionary Biology, 6: 381398. doi: $\underline{10.1007 / 978-1-4684-9063-3 \quad 14}$

LOngo, G., Montévil, M., Sonnenschein, C. \& Soto, A.M. (2015): In search of principles for a theory of organisms. Journal of Biosciences, 40(5): 955-968. doi 10.1007/s12038-015-9574-9

Mallet, J., Besansky, N. \& HAHN, M.W. (2015): How reticulated are species? Bioessays, 38: 140149. doi: $10.1002 /$ bies. 201500149

MALLON, R. (2006): 'Race': normative, not metaphysical or semantic. Ethics, 116: 525-551. doi: $10.1086 / 500495$

MARTYNOV, A.V. (1909): Les Trichoptéres du Tibet oriental et du Tsaidam d'après les materiaux collectionnés par l'expédition de la Société Impériale Géographique Russe sous la direction de P. K. Kozlov. Annuaire du Musée Zoologique de l'Academie Imperiale des Sciences de St.-Pétersbourg, 14: 256-309.

MARTYNOV, A.V. (1915): Contributions à la faune des Trichoptères des possessions Russes dans l'Asie central. Annuaire du Musée Zoologique de l'Academie Imperiale des Sciences de St.-Pétersbourg, 19: 402-437.

MAYDEN, R.L. (1997): A hierarchy of species concepts: the denouement in the saga of the species problems. In. ClaridGE M.F., DAWAH, H.A., \& WILSON, M.R. (Eds.) Species: the units of biodiversity. London, Chapman and Hall, p. 381424.

MAYR, E. (1942): Systematics and the origin of species. New York, Columbia University Press, $334 \mathrm{pp}$.

MAYR, E. (1963): Animal species and evolution. Harvard University Press, Cambridge Mass., 797 pp.
MAYR, E. (1996): What is a species and what is not? Philosophy of Science, 63: 262-277. doi: $\underline{10.1086 / 289912}$

MAYR, E. (2002): The biology of race and the concept of equality. Daedalus, 131: 89-94.

MCLACHLAN, R. (1874-1880): A monographic revision and synopsis of the Trichoptera of the European fauna. Reprinted 1968. E.W. Classey Ltd. Hampton, Middlesex. doi: 10.5962/bhl.title.28556

MALICKY, H. (1971): Trichopteren aus Italien. Entomologische Zeitschrift, 81(23): 257-265.

MALICKY, H. (1974): Die Köcherfliegen (Trichoptera) Griechenlands. Übesicht und Neubeschreibungen. Annales Musei Goulandris, 2: 105-135.

Mallet, J. (2008): Hybridization, ecological races and the nature of species: empirical evidence or the ease of speciation. Philosophical Transactions of the Royal Society B, 363: 2971-2986. doi: $\underline{10.1098 / \mathrm{rstb} .2008 .0081}$

MALlON, R. (2014): Naturalistic approaches to social construction. In. ZALTA, E.N. (Ed.).Stanford Encyclopedia of Philosophy. (2014 Winter Edition). Available at https://plato.stanford.edu/archives/win 2014/entries/social-construction-naturalistic/ (Accessed 22.03.2018)

MoretTI, G., Szczesny, B. \& Tobias, W. (1994): Systematische Differenzierung innerhalb der Potamophylax cingulatus-Gruppe. Senckenbergiana Biologica, 74(1-2): 91-102.

NAOMI, S.-I. (2010): On the integrated frameworks of species concepts: Mayden's hierarchy of species concepts and the de Queiroz's unified concept of species. Journal of Zoological Systematics and Evolutionary Research, 49(3): 177-184. doi: 10.1111/j.1439-0469.2011.00618.x

NeBoISS, A. (1963): The Trichoptera types of species described by J. Curtis. Beiträge zur Entomologie, 13(5-6): 582-635.

NELSON, A. (1994): How could scientific facts be socially constructed?: Introduction: The dispute between constructivists and rationalists. Studies in the History and Philosophy of Science, 25(4): 535547. doi: 10.1016/0039-3681(94)90046-9

OlÁH, J. (2011): A new species of Potamophylax (Trichoptera, Limnephilidae) from Albania. Braueria (Lunz am See, Austria,) 38: 13-14. 
OlÁH, J., KovÁcs, T., SIVEC, I., SZIVÁK, I. \& URBANIC, G. (2012): Seven new species in the Chaetopteryx rugulosa species group: applying the phylogenetic species concept and the sexual selection theory (Trichoptera, Limnephilidae). Folia Historico Naturalia Musei Matraensis, 36: 51-79.

OlÁH, J. (2017): Is the genus Potamophylax highly polymorphic? Acta Entomologica Musei Nationalis Pragae, 57(1): 253-257.

OláH, J., ChVojKa, P., Coppa, G., GodunKo, R.J., LODOVICI, O., MAJECKA, K., MAJECKI, J., SzCZESNY, B., Urbanic, G. \& VAlle, M. (2015): Limnephilid taxa revised by speciation traits: Rhadicoleptus, Isogamus, Melampophylax genera, Chaetopteryx rugulosa, Psilopteryx psorosa species groups, Drusu bolivari, Annitella kosciuszkii species complexes (Trichoptera, Limnephilidae). $O$ puscula Zoologica, Budapest, 46(1): 3-117. doi: 10.18348/opzool.2015.1.3

Oláh, J., Beshkov, S., Chvojka, P., Ciubuc, C., COPPA, G., IBRAHIMI, H., KovÁCS, T., MEY, W. \& OLÁH jr., J. (2017): Revision of Drusinae subfamily (Trichoptera, Limnephilidae): divergence by paraproct and paramere, speciation in isolation by integration. Opuscula Zoologica, Budapest, 48 (Suppl.1): 3-228. doi: 10.18348/opzool.2017.S1.3

OlÁH, J. \& OlÁH, J. jr. (2017): Fine phenomics applied to the Nectopsyche genus (Trichoptera): species delineation by speciation traits. Opuscula Zoologica, Budapest, 48(2): 117-184. doi: 10.18348/opzool.2017.2.117

PATTEN, M.A. (2009): 'Subspecies' and 'race' should not be used as synonyms. Nature, 457: 147. doi: $\underline{10.1038 / 457147 \mathrm{c}}$

PATTEN, M.A. (2010): Null expectations in subspecies diagnosis. Ornithological Monographs, 67: 35-41. doi: 10.1525/om.2010.67.1.35

Phillimore, A.B. (2010): Subspecies origination and extinction in birds. Ornithological Monographs, 67: 42-53. doi: 10.1525/om.2010.67.1.42

Phillimore, A.B. \& OWENS, I.P.F. (2006): Are subspecies useful in evolutionary and conservation biology? Proceedings of the Royal Society B, 273: 1049-1053. doi: $10.1098 / \mathrm{rspb} .2005 .3425$

PigluicCi, M. \& KAPlan, J. (2003): On the concept of biological race and its applicability to humans. Philosophy of Science, 70: 1161-1172. doi: $10.1086 / 377397$

PRATT, H.D. (2010): Revisiting species and subspecies of island birds for a better assessment of bio- diversity. Ornithological Monographs, 67: 79-89. doi: $\underline{10.1525 / \mathrm{om} .2010 .67 .1 .79}$

RELETHFORD, J.H. (2009): Race and global pattern of phenotypic variation. American Journal of Physical Anthropology, 139: 16-22. doi: 10.1002/ajpa.20900

DEQUEIROZ, K. (1985): The ontogenetic method for determining character polarity and its relevance to phylogenetic systematics. Systematic Zoology, 34: 280-299. doi: $10.1093 /$ sysbio/34.3.280

DEQUEIROZ, K. (2007a): A unified concept of species and its consequences for the future of taxonomy. Proceedings of the California Academy of Sciences, 56: 196-215.

DEQUEIROZ, K. (2007b): Species concepts and species delimitation. Systematic Biolog, 56(6): 879-886. doi: $\underline{10.1080 / 10635150701701083}$

DEQUEIROZ, K. (2011): Branches in the lines of descent: Charles Darwin and the evolution of the species concept. Biological Journal of the Linnean Society, 103: 19-35. doi: $10.1111 / \mathrm{j} .1095-8312.2011 .01634 . \mathrm{X}$

DeQueiroz, K. \& Donoghue, M.J. (1988): Phylogenetic systematics and the species problem. Cladistics 4: 317-338. doi: 10.1111/j.1096-0031.1988.tb00518.x

REMSEN, J.V. (2010): Subspecies as a meaningful taxonomic rank in avian Classification. Ornithological Monographs, 67: 62-78. doi: $10.1525 /$ om.2010.67.1.62

Robert, B. \& SCHMIDT, C. (1990): Zur Unterscheidung der Weibchen von Potamophylax cingulatus (Stephens, 1837) und Potamophylax latipennis (Curtis, 1834) (Trichoptera: Limnephilidae). Entomologische Zeitschrift, 100(16): 306310 .

Rosenberg, N.A., Pritchard, J.K., Weber, J.L., CANN, H.M., KIDD, K.K., ZhIVOTOVSKY, L.A. \& FELDMAN, M.W. (2002): Genetic structure of human populations. Science, 298: 2381-2385. doi: $10.1126 /$ science. 1078311

SEIFERT, B. (2014): A pragmatic species concept applicable to all eukaryotic organisms independent from their mode of reproduction or evolutionary history. Soil Organisms, 86(1): 85-93.

SESARDIC, N. (2010): Race: a social destruction of a biological concept. Biology \& Philosophy, 25: 143 162. doi 10.1007/s10539-009-9193-7

SowA, R. \& SzczeSnY, B. (1970): Stoneflies (Plecoptera) and caddisflies (Trichoptera) in the area of 
the Babia Góra Mtn. Ochrona Przyrody, 35: 221268.

STEPHENS, J.F. (1836-1837): Illustrations of British Entomology. Volume 6, p. 146-234. doi: $10.5962 /$ bhl.title. 8133

ŠTRKALJ, G. (2006): The study of human variation. Anthropologie, 44(2): 123-126.

SZCZESNY, B. (1990): Potamophylax cingulatus Stephens - a polymorphic species? Trichoptera Newsletter, 17: 11-13.

TEMPLETON, A.R. (1999): Human races: a genetic and evolutionary perspective. American Anthropologist, 100(3): 632-650. doi: 10.1525/aa.1998.100.3.632

TEMPLETON, A.R. (2013): Biological races in humans. Studies in History and Philosophy of Biological and Biomedical Sciences, 44(3): 262-271. doi: $10.1016 / \mathrm{j}$. shpsc.2013.04.010

TetUSHKIN, E.Ya. (2001): Genetics and the origin of human "races". Russian Journal of Genetics, 37(8): 853-867. Translated from Genetica, 37(8): 10291045. doi: 10.1023/A:1016735029740

Tobias, J.A., Seddon, N., Spottiswoode, C.N., PilGRIM, J.D., FISHPOOL, L.D.C. \& ColLar, N.J. (2010): Quantitative criteria for species delimitation. Ibis, 152: 724-746. doi: 10.1111/j.1474-919X.2010.01051.x
Velasco, J.D. (2008): Species concepts should not conflict with evolutionary history, but often do. Studies in History and Philosophy of Biological \& Biomedical Sciences, 39: 407-414. doi: $\underline{10.1016 / j . s h p s c .2008 .09 .007}$

WHEELER, Q.D. (2008): The new taxonomy. The Systematic Association Special Volume Series 76, $237 \mathrm{pp}$.

WILSON, E.O. \& BROWN, W.L. Jr. (1953): The subspecies concept and its taxonomic application. Systematic Zoology, 2: 97-111. doi: 10.2307/2411818

WINKER, K. (2010): Is it a species? Ibis, 152: 679-682. doi: $10.1111 / \mathrm{j} .1474-919 X .2010 .01061 . \mathrm{x}$

Yudell, M., RoberTs, D., DeSAlle, R. (2016): Taking race out of human genetics. Science, 351(6273): 564-565. doi: 10.1126/science.aac4951

ZACHOS, F.E. \& LOVARI, S. (2013): Taxonomic inflation and the poverty of the phylogenetic species concept - a reply to Gippoliti and Groves. Hystrix, the Italian Journal of Mammalogy, 24(2): 142-144. doi: 10.4404/hystrix-24.1-8849

ZINK, R.M. (2004): The role of subspecies in obscuring avian biological diversity and misleading conservation policy. Proceedings of the Royal Society B, 271: 561-564. doi: 10.1098/rspb.2003.2617 